\title{
Making the case for a formal Anthropocene Epoch: an analysis of ongoing critiques
}

\author{
Jan Zalasiewicz ${ }^{1 *}$, Colin N. Waters ${ }^{1,2}$, Alexander P. Wolfe ${ }^{3}$, \\ Anthony D. Barnosky ${ }^{4}$, Alejandro Cearreta ${ }^{5}$, Matt Edgeworth ${ }^{6}$, \\ Erle C. Ellis ${ }^{7}$, lan J. Fairchild ${ }^{8}$, Felix M. Gradstein ${ }^{9}$, Jacques Grinevald ${ }^{10}$, \\ Peter Haff ${ }^{11}$, Martin J. Head ${ }^{12}$, Juliana A. Ivar do Sul ${ }^{13}$, Catherine Jeandel ${ }^{14}$, \\ Reinhold Leinfelder ${ }^{15}$, John R. McNeill ${ }^{16}$, Naomi Oreskes ${ }^{17}$, \\ Clément Poirier ${ }^{18}$, Andrew Revkin ${ }^{19}$, Daniel deB. Richter ${ }^{11}$, Will Steffen ${ }^{20}$, \\ Colin Summerhayes ${ }^{21}$, James P. M. Syvitski ${ }^{22}$, Davor Vidas ${ }^{23}$, \\ Michael Wagreich ${ }^{24}$, Scott Wing ${ }^{25}$, and Mark Williams ${ }^{1}$
}

With 4 figures

\footnotetext{
Authors' addresses:

${ }^{1}$ Department of Geology, University of Leicester, University Road, Leicester LE1 7RH, UK.

2 British Geological Survey, Keyworth, Nottingham NG12 5GG, UK.

${ }^{3}$ Department of Biological Sciences, University of Alberta, Edmonton, AB T6G 2E9, Canada.

4 Jasper Ridge Biological Preserve, Stanford University, Stanford, CA 94305, USA

5 Departamento de Estratigrafía y Paleontología, Facultad de Ciencia y Tecnología, Universidad del País Vasco UPV/EHU, Apartado 644, 48080 Bilbao, Spain.

${ }^{6}$ School of Archaeology and Ancient History, University of Leicester, University Road, Leicester LE1 7RH, UK.

7 Department of Geography and Environmental Systems, University of Maryland Baltimore County, Baltimore MD 21250, USA.

${ }^{8}$ School of Geography, Earth and Environmental Sciences, University of Birmingham, Birmingham B15 2TT, UK.

${ }^{9}$ Natural History Museum, Postboks 1172, Blindern, 0318 Oslo, Norway.

10 IHEID, Chemin Eugène Rigot 2, 1211 Genève 11 Switzerland.

11 Nicholas School of the Environment, Duke University, 9 Circuit Drive, Box 90238, Durham, NC 27708, USA.

12 Department of Earth Sciences, Brock University, 1812 Sir Isaac Brock Way, St. Catharines, ON, L2S 3A1 Canada.

13 Institute of Oceanography, Federal University of Rio Grande, Av. Italia, km 8, Carreiros Rio Grande, RS, 96201-900, Brazil.

${ }^{14}$ LEGOS (CNRS/CNES/IRD/Université Paul Sabatier), 14 avenue Edouard Belin, 31400 Toulouse, France.

15 Department of Geological Sciences, Freie Universität Berlin, Malteserstr. 74-100/D, 12249 Berlin, Germany.

${ }^{16}$ Georgetown University, Washington DC, USA.

17 Department of the History of Science, Harvard University, Cambridge, MA 02138, USA.

${ }^{18}$ Morphodynamique Continentale et Côtière, Université de Caen Normandie, CNRS; 24 rue des Tilleuls, F-14000 Caen, France.

${ }^{19}$ Dyson College Institute for Sustainability and the Environment, Pace University, Pleasantville, NY, USA.

20 The Australian National University, Canberra ACT 0200, Australia.

${ }^{21}$ Scott Polar Research Institute, Cambridge University, Lensfield Road, Cambridge CB2 1ER, UK.

22 University of Colorado-Boulder Campus, Box 545, Boulder CO, 80309-0545, USA.

${ }^{23}$ Law of the Sea and Marine Affairs Programme, The Fridtjof Nansen Institute, Norway.

${ }^{24}$ Department of Geodynamics and Sedimentology, University of Vienna, A-1090 Vienna, Austria.

25 Department of Paleobiology, National Museum of Natural History, Smithsonian Institution, Washington DC, 20013 USA.

* Corresponding author: jaz1@ leicester.ac.uk
} 


\begin{abstract}
A range of published arguments against formalizing the Anthropocene as a geological time unit have variously suggested that it is a misleading term of non-stratigraphic origin and usage, is based on insignificant temporal and material stratigraphic content unlike that used to define older geological time units, is focused on observation of human history or speculation about the future rather than geologically significant events, and is driven more by politics than science. In response, we contend that the Anthropocene is a functional term that has firm geological grounding in a well-characterized stratigraphic record. This record, although often lithologically thin, is laterally extensive, rich in detail and already reflects substantial elapsed (and in part irreversible) change to the Earth System that is comparable to or greater in magnitude than that of previous epoch-scale transitions. The Anthropocene differs from previously defined epochs in reflecting contemporary geological change, which in turn also leads to the term's use over a wide range of social and political discourse. Nevertheless, that use remains entirely distinct from its demonstrable stratigraphic underpinning. Here we respond to the arguments opposing the geological validity and utility of the Anthropocene, and submit that a strong case may be made for the Anthropocene to be treated as a formal chronostratigraphic unit and added to the Geological Time Scale.
\end{abstract}

Key words. Anthropocene, Earth System, Geological Time Scale, Holocene, Stratigraphy.

\section{Introduction}

Since the Anthropocene was conceptualized as a new and distinct epoch of Earth history (Crutzen and Stoermer 2000, Crutzen 2002), and more specifically since it has been suggested and analyzed as a potential formal addition to the International Chronostratigraphic Chart (and Geological Time Scale) (e.g. Zalasiewicz et al. 2008, Williams et al. 2011, Waters et al. 2014), as a distinct geological epoch and series to succeed the Holocene (Waters et al. 2016), critics have questioned both the concept in general, and its potential for such formalization.

Such critical examinations (e.g. Autin and Holbrook 2012, Finney 2014, Gibbard and Walker 2014, Visconti 2014, Edwards 2015, Smil 2015, Walker et al. 2015, Braje 2016, Finney and Edwards 2016) are an essential part of the process of considering modification of the International Chronostratigraphic Chart and the Geological Time Scale upon which it is based. This construct, enabling precise navigation, correlation and communication within the 4.6 billion years of Earth history, may be considered the backbone of geology; consequently, the process of adding to it, or amending existing units, is justly a slow, incremental and conservative process. Nevertheless, changes to it continue to be made, whether these be boundary modifications, such as recently took place for the Quaternary Period (Gibbard and Head 2009), finer subdivisions (currently in discussion for the Holocene Epoch: Walker et al. 2012), or the construction of new units, such as the Ediacaran Period (Knoll et al. 2006). Such changes only come about after exhaustive analysis and balanced discussion. Indeed, a number of established units still lack fully agreed and ratified boundary definitions (see Gradstein et al. 2012).

The Anthropocene exhibits a number of distinctive and novel features (Zalasiewicz et al. 2012), hence the vigorous debate currently surrounding its possible adoption as a formal stratigraphic unit. Even so, the Anthropocene possesses many of the prerequisite traits for formal stratigraphic recognition (Waters et al. 2016). If some of the arguments made against the Anthropocene are established as convincing and unanswerable, then they might indeed represent serious barriers to formal inclusion into the Geological Time Scale. But if the criticisms can be reasonably addressed, then doing so would demonstrate the viability of potential formalization, following strict adherence to geological protocols.

Here we respond to the substantive published arguments that are intended to dispute the formalization of the Anthropocene. We take the position (argued for by Finney and Edwards 2016 and others) that formally recognizing the Anthropocene as an addition to the Geological Time Scale must rely on the geological evidence as the decisive factor. If progress is to be made from the stratigraphic perspective, it is essential to disentangle the geological evidence from other ramifications, including societal ones. The objective of the present discussion is to assess the case for the Anthropocene as a bona fide chronostratigraphic unit. 


\section{Critiques and responses}

Published concerns may be placed within eight categories, each of which we list as a heading below, along with counter-arguments offered to each concern:

\subsection{The term Anthropocene has misleading implications}

This criticism includes components that relate to the definition of the Holocene, to the origin of the term 'Anthropocene' outside of stratigraphy, to its imputed faulty etymology, to the historical priority of the 'Atomic Age', and to the truncation of the Holocene. We consider each of these components in turn.

\subsubsection{Definition of the Holocene}

Gibbard and Walker (2014) proposed that it is the "anthropogenic signature that is the hallmark of the Holocene, setting it apart from previous interglacials, and taken as a fundamental justification for its status as a time-stratigraphic unit of Series/Epoch rank as it is currently defined (Walker et al. 2009)". Therefore, there already exists a suitable geological term (i.e. the Holocene), an argument sometimes paraphrased as 'the human card cannot be played twice', with the history of human impact itself commonly being seen as one of 'transient states and multiple episodes' (see Gibbard and Lewin 2016)

In response, we note that humans have been components of the Earth System not only throughout the Holocene but also in the Late Pleistocene. Even so, equating the Holocene with human influence is nowhere explicit within the formal definition of the Holocene in the Greenland (NGRIP) ice-core, which is based upon the physical expression of a climatic shift - notably changes in ice dustiness and deuterium excess (Walker et al. 2009) - that is not attributed to anthropogenic activity. Following the phase of climatic warming marking the end of the last cold episode (Younger Dryas Stadial) of the Pleistocene, the Holocene, for most of its duration, has been an interval of relative stability for not only climate, but for most of the fundamental Earth System parameters. This is not to say that humans did not change the planet during the Holocene: overwhelming evidence exists to show millennia of population growth and mounting technological and cultural sophistication, all leading to long-term anthropogenic environmental changes. Arguably, human influence may even have prolonged Holocene conditions, if human activities were the main factor be- hind the very gentle rise in atmospheric $\mathrm{CO}_{2}$ beginning about 7000 BP from $\sim 260$ to $\sim 280 \mathrm{ppm}$, a rise that may have postponed a glacial inception (Ruddiman 2013, Ruddiman et al. 2015, Ganopolski et al. 2016). Physical modifications were also made by humans to landscapes and terrestrial sediments, and these modifications spread slowly and diachronously across the terrestrial world over millennia (Edgeworth et al. 2015), when the human population was much smaller than it is now. These changes are quite different in magnitude and rate to the larger-scale, in part novel and increasingly synchronous changes of the last 1-2 centuries (that also affect the marine realm: Wilkinson et al. 2014), with their marked upward inflection in the mid-20 ${ }^{\text {th }}$ century (Steffen et al. 2015a, 2015b, Waters et al. 2016). Evidence in the sedimentary record now clearly shows two distinct stratigraphic episodes since 11,700 years ago, one that might reasonably be described as the Holocene (up until the mid- $20^{\text {th }}$ century) and the other as the Anthropocene (since the mid$20^{\text {th }}$ century). The critical factor here is not the fact of any human impact but fundamental differences between the Holocene and the Anthropocene as regards the magnitude, rate, and global synchroneity of change recorded in their respective stratigraphic signatures.

\subsubsection{Origin of the term 'Anthropocene' outside of stratigraphy}

Finney and Edwards (2016) commented that "In contrast to all other units of the ICS chart, the concept of the Anthropocene did not derive from the stratigraphic record. It arose with Paul Crutzen (2002), a Nobel laureate in chemistry". This is an implied criticism that Crutzen is neither geologist nor stratigrapher (see Steffen 2013 for more detail). It arises from the assumption that, because Crutzen focused on evidence from the Earth System sciences rather than from the geological sciences, the concept was not necessarily of stratigraphic interest. Yet, this is not the case, as becomes evident from exploring the history of the term.

The antecedents of the Anthropocene concept of Crutzen (2002; see also Crutzen and Stoermer 2000) arguably date from the beginnings of organized stratigraphy (see Hamilton and Grinevald 2015), in the form of Georges-Louis Leclerc, Comte de Buffon's "Seventh Epoch" of 1778, through to Antonio Stoppani's late $19^{\text {th }}$ century “Anthropozoic", and the work of Vladimir Vernadsky in the early to mid- $20^{\text {th }}$ century. While these antecedents do not explicitly address the stratigraphic record, they recognize a significant change within the narrative of Earth history. With re- 
gard to anthropogenically-influenced physical strata, these too have been regarded for many years as distinctive geological deposits. For instance, Eduard Suess $(1862,1897)$ mapped urban strata as a geological unit (Schuttdecke), recording changes in the anthropogenic strata of Vienna, while Robert Sherlock catalogued human impacts on a geological scale in his book Man as a Geological Agent (1922). The history of the Anthropocene concept is briefly outlined in Steffen et al. (2011), whereas more exhaustive chronicles have been presented by Grinevald (2007) and Hamilton and Grinevald (2015).

Nevertheless, it was long the case that most of the geological community thought of the human impact on Earth's geology as trivial and fleeting by comparison with large-scale geological processes acting over millions of years. That general opinion began to change in the second half of the $20^{\text {th }}$ century, when the magnitude of human-driven geological change became more widely appreciated as of sufficient scale and persistence to be reflected using geologically-based terms such as the 'Anthrocene' of Revkin (1992). This observation was crystallized within the Earth System science (ESS) community with the first utterance of 'Anthropocene' by Paul Crutzen, after which the term began to be widely used (see also Steffen et al. 2016). Crutzen's proposal, though coming from an atmospheric chemist working within the ESS community, was nevertheless proposed overtly to represent "the present, in many ways human-dominated, geological epoch" (Crutzen and Stoermer 2000). This in effect represents a hypothesis, one that the Anthropocene Working Group (hereafter AWG) is testing explicitly in relation to formal stratigraphy (Waters et al. 2016 and references therein).

The assembly and consideration of evidence involved in this process has modified and elaborated the concept. For instance, Crutzen, working before much of the geological evidence had been compiled, envisaged the Anthropocene beginning in the late $18^{\text {th }}$ century with the onset of the industrially-related rise of anthropogenic $\mathrm{CO}_{2}$ concentrations, and this seemed also the logical starting date following preliminary geological analysis (Zalasiewicz et al. 2008). Later, as the stratigraphic information was assembled it became clear that, while industrialization was an essential prerequisite for the Anthropocene, the array of resulting stratigraphic signals only became sufficiently strongly and globally expressed to serve as an effective boundary marker in the mid- $20^{\text {th }}$ century (Waters et al. 2014, 2016, Zalasiewicz et al. 2015a).

\subsubsection{Imputed faulty etymology}

The Anthropocene has been said to be of 'dubious etymology' (Walker et al. 2015). Indeed, the term Anthropocene was at least in part a spur-of-the-moment improvisation by Paul Crutzen, then unaware that the limnologist Eugene Stoermer had independently coined the term some years previously (Steffen 2013). The term Anthropocene is therefore not a carefully constructed neologism, in keeping with the reality that geological time unit terms in general are not the most rigorously constructed or consistent items of language. For instance, to have the Silurian and Ordovician named after obscure ancient Welsh tribes has no apparent inherent logic from a stratigraphic perspective, while the Quaternary continues as a formal unit despite the fact that the Primary and Secondary have long fallen into disuse and the Tertiary is no longer an official unit. The strict meaning of 'Anthropocene' in the Greek (juxtaposing 'human' and 'new'), rather than being one that 'makes no sense at all' (Walker et al. 2015; see also Visconti 2014), is consistent with the fact that the Anthropocene, in its stratigraphic sense following Crutzen and Stoermer (2000), reflects humans as the dominant force driving marked and globally near-synchronous changes to some key Earth processes, and is concordant with the 'etymologically curious' but 'popularly embraced' (Gibbard and Lewin 2016) use of the suffix '-cene' for all Cenozoic epochs. This follows several millennia of significant although diachronous and/or incremental human impact that has been interpreted in terms of an informal Palaeoanthropocene time unit - explicitly not a chronostratigraphic term of geology - by Foley et al. (2013). It goes almost without saying that this dominance is captured primarily within the sedimentary record, and does not extend to igneous and metamorphic rocks; but, that was also the case with the origin of most of the rock record that defines previous epochs.

The Anthropocene is, in practice, a widely accessible term that evokes human change to the planet, which grew exponentially as population rose past 1 billion in 1800 to 2.5 billion in 1950 and to 7.5 billion now. It has, in a short time, clearly become by far the dominant term to describe recent human impacts. Since 2000, the term has been used in more than 1300 scientific papers, which collectively have been cited over 12,000 times (Fig. 1) and in many conference sessions in a diversity of disciplines. It has given rise to at least four scientific journals and periodicals, is in the title of more than 100 books, and frequently ap- 
pears in news stories. The term has entered the Oxford English Dictionary and now is widely used and generally understood in wider discourse. It would make little sense to rename it into something envisaged to be of greater etymological purity - even if such a name could be composed and widely agreed. The Anthropocene, whether or not it becomes formalized stratigraphically, seems to be here to stay. Formalization of geological usage would in these circumstances enhance stability of meaning and precision of scientific communication.

\subsubsection{The "Atomic Age" has historical priority}

Finney and Edwards (2016) have suggested that "the 'Atomic Age' has historical priority" over the term Anthropocene. It is true that if the Anthropocene were to be defined in 1946, then yes, the Atomic Age was coined earlier (in 1946 in fact). But stratigraphic terminology is not bound by the strict rules of priority that apply to the nomenclatural codes for biology. The International Stratigraphic Guide (ISG, Salvador 1994) supports priority in general but states: "Priority alone does not justify displacing a well-established name by one not well known or only occasionally used: nor should an inadequately established name be preserved merely on account of priority (Salvador 1994, p. 23; also see p.22). The"Atomic Age" neither conveys the meaning of the Anthropocene nor is formulated in a way that would make it acceptable to ISG itself as a formal chronostratigraphic term.

\subsubsection{Truncation of the Holocene}

Stability is an important characteristic of the Geological Time Scale, which has led the International Commission on Stratigraphy to adopt a necessarily conservative approach. With this in mind, Head and Gibbard (2015, p. 24) noted that the Anthropocene defined at the rank of series/epoch would truncate the Holocene, which "has included modern deposits since its original inception in the late nineteenth century (Gervais 1867-1869)", and sever it from its traditional and historical contexts. They also noted that such truncation would require stratigraphers always to discriminate Anthropocene strata, which would be impractical for routine mapping and lead to the unwieldy term "Holocene-Anthropocene" for these undifferentiated deposits. Head and Gibbard (2015) noted that the Anthropocene defined at the rank of stage, or even substage, would obviate all these difficulties.

We acknowledge that the truncation of the Holocene will cause some disruption. But this is true of any new-

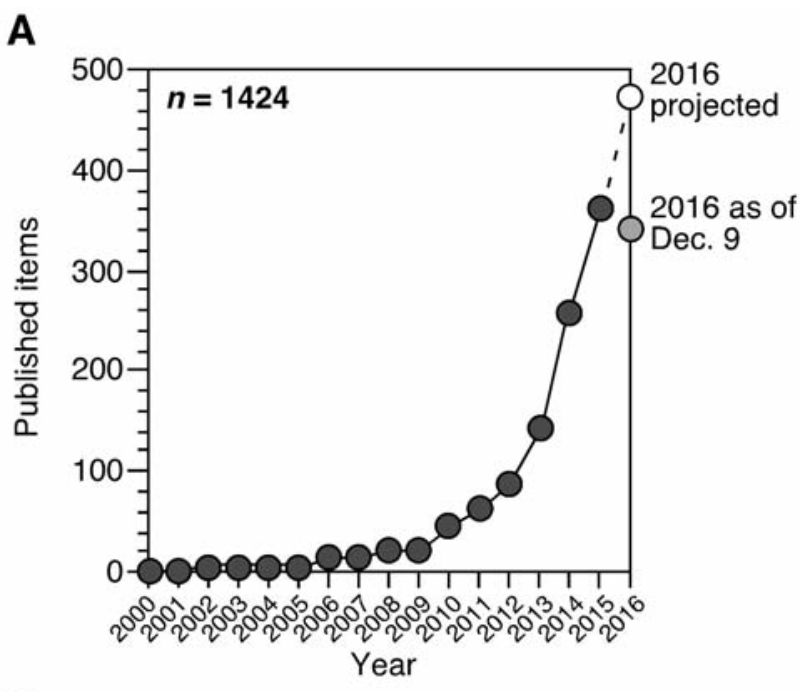

B

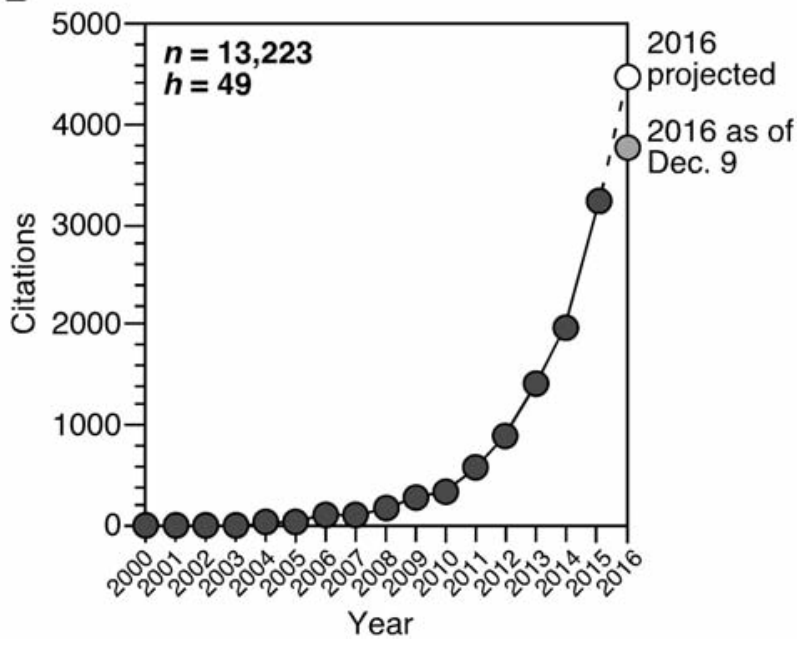

Fig. 1. The history of the term Anthropocene by (A) publications using this term in title, abstract, or text), and (B) citation of these works, as of December 9, 2016 accessing of the Scopus database (https://www.scopus.com/). Data are extrapolated to the end of 2016 using linear regressions of the 2013-2015 limbs of each graph. In (b), the score for $h$ (commonly: h-index) refers to the number of items tallying $\mathrm{h}$ or more citations.

ly or redefined boundary within the Geological Time Scale. Examples include the lowering of the Pleistocene Series boundary, which resulted in the transfer of the Gelasian Stage from the Upper Pliocene to the Lower Pleistocene (Gibbard and Head 2009), and the wholesale refashioning of the Ordovician System (Webby 1998), which decidedly changed the character of that system's subdivision in order to produce a more widely useful entity. The Ordovician, of course, has a historical context even longer than that of the Holocene. It might also be remembered that Gervais when 
introducing the term Holocene in 1869 was living at a time soon after the end of the Little Ice Age with environmental conditions occupying Holocene norms. He could not have foreseen the unprecedented changes occurring in the mid-20th century through anthropogenic forcing of the Earth System. It is also necessary to consider the scope and magnitude of these changes. They are significantly greater than the changes proposed to subdivide the Holocene into subseries (Walker et al. 2012), and it would therefore run counter to hierarchical logic to define the Anthropocene at a rank lower than epoch/series. Finally, units of the Geological Time Scale are defined only by their base. The top of the Holocene is essentially undefined (or defined only by default). Defining the Anthropocene at the rank of series/epoch would not cause a change to the existing formal definition of the Holocene based upon an abrupt shift in deuterium excess values in the NGRIP ice-core (Walker et al. 2009). Indeed, defining a base for the Anthropocene provides completeness for our understanding of the Holocene, with both top and base defined. Such closure hence may be considered an advantage for the understanding of the Holocene, both stratigraphically and conceptually. On a global scale, this has been environmentally a highly stable epoch, strongly contrasting with the Anthropocene, in which a number of key planetary boundary conditions, notably associated with the carbon, nitrogen and phosphorus cycles, are clearly outside the range of natural variability observed in the Holocene (Waters et al. 2016).

As regards the related point raised concerning discrimination of Anthropocene from Holocene strata in geological mapping, we note firstly that the primary units involved in such mapping are lithostratigraphic, rather than chronostratigraphic; the two need not and commonly do not coincide, especially as many lithostratigraphic boundaries are diachronous. For instance, in the Lower Paleozoic rocks of the central Welsh Basin, the Ordovician-Silurian boundary occurs within a well-characterized lithostratigraphic unit, the Cwmere Formation (Davies et al. 1997), and is typically recognized by the incoming of a particular species of fossil graptolite, on the assumption that this appears at the same time in this basin as at the type section, Dob's Linn in Scotland (Melchin et al. 2012). To state that the Cwmere Formation is of Late Ordovician-Llandovery age is no less unwieldy.

More widely, it has long been, and remains the case, that chronostratigraphic boundaries at any hierarchical level can be difficult or impossible to locate precisely in some rock successions. Hence, for instance, the widespread use of 'Permo-Triassic' for the poorly fossiliferous terrestrial successions of this age in the UK and elsewhere, where the boundary - elsewhere one of the most striking in stratigraphy - is difficult to pinpoint. The 'Plio-Pleistocene', though no longer advovated since the lowering of the Pleistocene base, remains in use (e.g. Martinez-Boti et al. 2015), as do the 'Cambro-Ordovician', the 'Siluro-Devonian' and other such combinations. Though awkward, these are a pragmatic response to the patchiness of boundarydefining evidence in strata, or simply used to refer to a combined unit.

For the Anthropocene, one might argue that the wide array of stratigraphic proxy data (Waters et al. 2016) that may be used to identify a post-mid $-20^{\text {th }}$ century stratal unit in both terrestrial and marine successions, even far from direct human influence (e.g. Wolfe et al. 2013, Smith et al. 2016) suggest that the use of a 'Holo-Anthropocene undivided' unit may in fact be less needed in practice relative to the combination-terms for more ancient strata cited as examples above. Ford et al. (2014) demonstrated how post-Second World War anthropogenic deposits can be mapped in Swansea, Wales, as a distinct lithostratigraphic (but also chronostratigraphic) unit from earlier successions associated with the Industrial Revolution, another striking example being the proposed Teufelsberg formation in Berlin (Zalasiewicz et al. 2016b).

\subsection{The spatial and temporal scales of the Anthropocene are insignificant and cannot be consistently recognized or correlated}

\subsubsection{Spatial scales}

Anthropocene successions are typically relatively thin, and have been argued to be "effectively unresolvable in most deep-sea settings" which represent a large fraction of the planetary surface (Walker et al. 2015). Among the concerns are: "Published logs with geochemical signatures of human impact are at most a few tens of centimetres thick", while the stratigraphic record has been described as "minimal", "negligible", "marginal" and "impoverished" (Finney and Edwards 2016), and there 'has not yet been a major transformation of sediment systems themselves' (Gibbard and Lewin 2016). Moreover, given that the most robust body of evidence now points to locating a potential Holocene-Anthropocene boundary in the mid- $20^{\text {th }}$ century, the criticism has aris- 
A

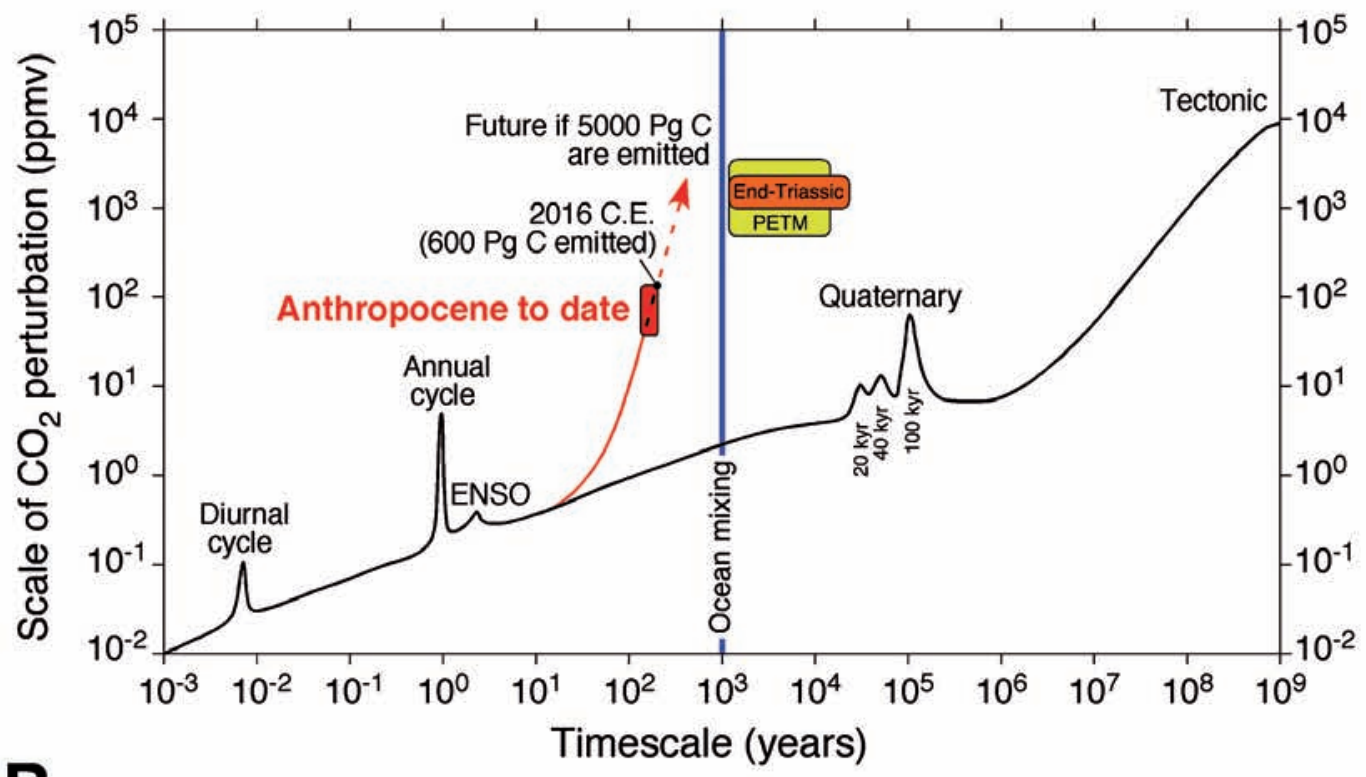

B

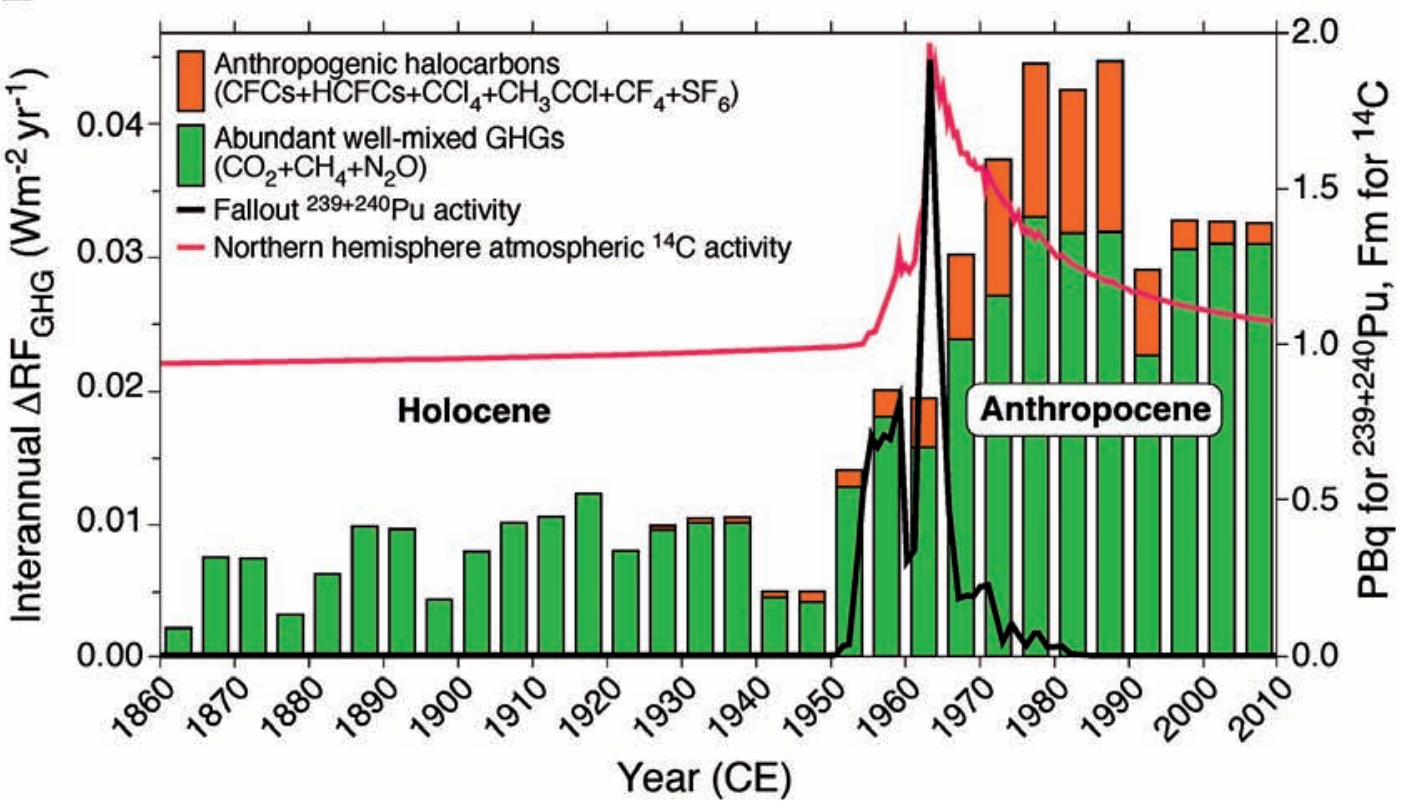

Fig. 2. Examples of Earth System perturbations during the Anthropocene. (A) Log-log plot of atmospheric $\mathrm{CO}_{2}$ concentration versus time, modified from Falkowski et al. (2000) and Royer (2016). Despite its brevity, the magnitude of the $\mathrm{CO}_{2}$ perturbation that characterizes the Anthropocene (600 Pg C emitted to date) is intermediate between those of Quaternary glacial-interglacial cycles and deeper time (e.g., the end-Triassic mass extinction and the Paleocene-Eocene thermal maximum); stratigraphic proxies for this perturbation include direct $\mathrm{CO}_{2}$ signals in polar ice, a marked carbon isotope anomaly and globally distributed fly ash within recent strata (see Waters et al.2016). (B) Estimated annual growth of greenhouse-gas radiative forcing $\left(\mathrm{RF}_{\mathrm{GHG}}\right)$ between 1860 and 2010, based on five-year bins and data synthesized in the IPCC Fifth Assessment Report (Myhre et al. 2013). Rapid acceleration of $\mathrm{RF}_{\mathrm{GHG}}$ growth characterizes the second half of the $20^{\text {th }}$ century, as do the important contributions from exclusively anthropogenic halocarbons, particularly between 1960 and 1995 . Although $\mathrm{RF}_{\mathrm{GHG}}$ growth rate has possibly stabilized in the early $21^{\text {st }}$ century, it remains more than three times those of the pre-1950 interval. The atmospheric $\mathrm{CO}_{2}$ inventory continues to grow, however, at rates consistently surpassing $2 \mathrm{ppm} \mathrm{yr}^{-1}$. Superposed on GHG radiative forcing growth are time-series of anthropogenic radionuclide activities $\left({ }^{14} \mathrm{C}\right.$ and $\left.{ }^{239+240} \mathrm{Pu}\right)$ derived primarily from nuclear weapons testing, and providing robust independent stratigraphic markers for a mid-20 $0^{\text {th }}$ century onset for the Anthropocene (Zalasiewicz et al. 2015a). PBq - petabecquerel, Fm - Fraction modern. 
en that: "Locating a boundary at 1945 would be difficult for anthropogenic isotope shifts in greenhouse gases that have been rising for 100 years or more" (Finney and Edwards 2016).
Anthropocene strata may be commonly thin, but they nonetheless reflect a major Earth System perturbation, are laterally extensive, and can include rich stratigraphic detail (Figs. 2 and 3). Within sediment-starved or dis-
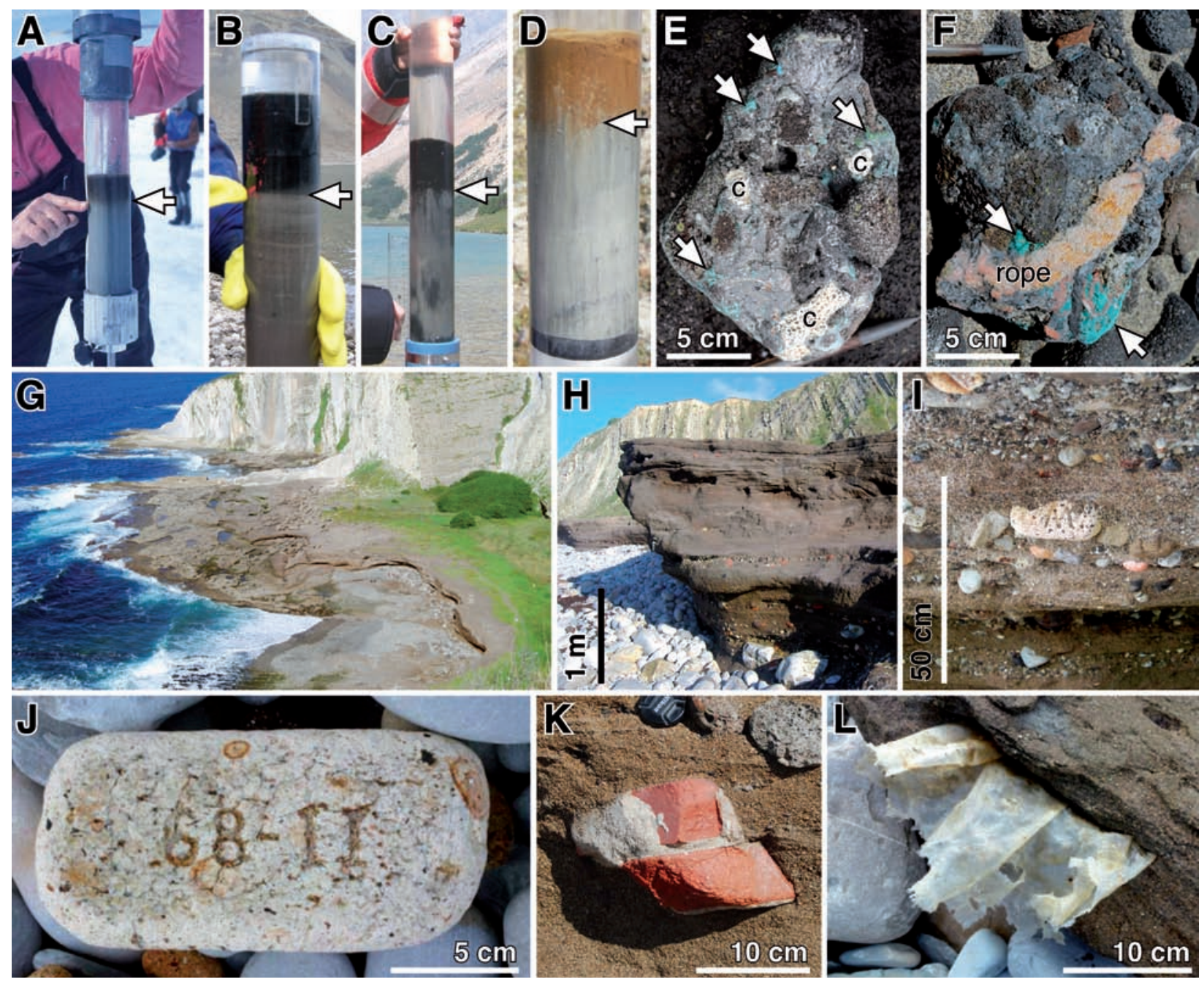

Fig. 3. Geological materials recording the Anthropocene. (A-D) Lake sediments showing marked stratigraphic transitions from inorganic proglacial sediments to highly organic non-glacial sapropel (arrows). In each case, the sedimentological change reflects sediment starvation associated with the retreat of up-valley glaciers (Wolfe et al. 2013). Examples are from southwest Greenland (A: Qipisarqo Lake, $61.01^{\circ} \mathrm{N}, 47.45^{\circ} \mathrm{W}$ ), Spitsbergen in the Svalbard archipelago (B: Kongressvatnet, $78.01^{\circ} \mathrm{N}, 13.97^{\circ} \mathrm{E}$ ), and the Canadian Rocky Mountains (C: McConnell Lake, 51.63 ${ }^{\circ} \mathrm{N}, 115.97^{\circ} \mathrm{W}$; D: Curator Lake, $\left.52.80^{\circ} \mathrm{N}, 117.87^{\circ} \mathrm{W}\right)$. (E-F) Plastiglomerates from Kamilo Beach on the Island of Hawaii $\left(18.98^{\circ} \mathrm{N}, 155.60^{\circ} \mathrm{W}\right)$, where molten plastics (arrows) have fused basalt clasts and coral fragments (c in E) to form an assortment of novel beach lithologies (Corcoran et al. 2014). A section of orange rope is evident in (F). (G-J) Beach facies off the Bilbao estuary, Cantabrian coast, northern Spain $\left(43.38^{\circ} \mathrm{N}, 3.02^{\circ} \mathrm{W}\right)$. (G) Overview of the Tunelboca beachrock (up to $12 \mathrm{~m}$ thick), which discordantly overlies Eocene sediments and comprises a carbonate-cemented admixture of slag and rubble dumped at sea between 1902 and 1995, and natural materials include calcareous bivalves (Irabien et al. 2015). (H) The Gorrondatxe beachrock, immediately east of Tunelboca, has a thickness of 3-7 m that includes a well-cemented lower conglomeratic facies overlain by a more weakly-cemented sandy unit, both containing rich arrays of anthropogenic technofossils. (I) Rounded and fragmented bricks in the lower facies at Tunelboca, preserving inscriptions (Astibia 2012). (J) An extracted brick from the Tunelboca beachrock conglomeratic facies. (K) A more recent brick and mortar assemblage from the overlying sandy facies at Tunelboca. (L) Plastic sheeting within the upper Gorrondatxe beachrock. 
tal marine basins, the thicknesses of sediments accumulated during the Anthropocene are small, although in some settings the marine record clearly reflects a unique Anthropocene signature. For example, within the central Santa Barbara Basin, varved deposits allow recognition of a layer deposited in 1950, which occurs at depths below seabed of $0.15-0.20 \mathrm{~m}$, while deposits from the last two millennia span only $2 \mathrm{~m}$ (Schimmelmann et al. 2013). In such a setting, the application of accelerator mass spectrometry ${ }^{14} \mathrm{C}$ activities coupled with short-lived radioisotope inventories $\left({ }^{137} \mathrm{Cs}\right.$ and ${ }^{210} \mathrm{~Pb}$ ), combined with varve studies and recognition of geochemical signals, clearly allows the distinction of Anthropocene strata within marine cores.

More widely, a clear Anthropocene imprint has been demonstrated even in distal or slowly-accumulating deep marine oozes such as those of the Arctic (Gobeil et al. 2001). Any sample of these will now typically contain microplastics (Ivar do Sul and Costa 2014, Zalasiewicz et al. 2016a and references therein), include detectable traces of artificial radioactive fallout (Waters et al. 2015), and will also likely include the spherical carbonaceous particles (of fly ash) that have been found globally in terrestrial settings (Rose 2015). Hence, while such distal deposits may be thin, and will often be mixed at a centimetre to decimetre scale by bioturbation with underlying sediments, they include a recognizable and unique set of stratigraphic signals.

Anthropocene strata may be recognized as distinct in many lakes, based on a variety of criteria (e.g. Wolfe et al. 2013; see Fig.3A-D herein). Within four lakes from Australia and New Zealand the Pu fallout signal (Fig. 2) commencing in 1954-1955 (the first appearance datum) is present within sediment profiles ranging from 0.5 to $1.7 \mathrm{~m}$ thick (Hancock et al. 2011), with accumulation rates of up to $30 \mathrm{~mm} \mathrm{yr}^{-1}$. Other Anthropocene deposits of substantial thickness abound. In the Clyde Estuary, Scotland, a 1954 datum is established with the lowest occurrence of polychlorinated biphenyls in the UK, recorded in cores to depths of $0.6 \mathrm{~m}$ (Vane et al. 2011). Considerably thicker successions can be achieved where direct human placement of deposits is considered, e.g. the up to $70 \mathrm{~m}$ of waste accumulated since 1947 in the Fresh Kills Landfill, Staten Island (USA), with a peak influx of garbage reaching 29,000 tons per day (Nagle 2008). There, artifact ages can clearly date the material deposited. The Teufelsberg formation (sensu Scheffold 2014), one of the human-made post-war (1950-1972) debris accumulations of Berlin, forms the highest elevation of the city and is up to $80 \mathrm{~m}$ thick.
Very considerable changes can be seen, too, in fluvial and coastal sedimentary successions markedly perturbed by landscape change and dam-building. For example, Irabien et al. (2015) describe a coastal succession in the Basque region of northern Spain that is up to $12 \mathrm{~m}$ thick, was largely derived from the tidal and wave reworking of iron slags, and includes brick and plastic debris (Fig. 3G-L). On a larger scale, Wang et al. (2011) described the fate of hundreds of cubic kilometres of sediment (equivalent to a metre-thick deposit covering areas of hundreds of thousands of square kilometres) carried to the coast in just five Asian rivers (out of about 6250 major rivers worldwide). Sediment yield was first enhanced over $\sim 1000$ years through landscape change, then decreased dramatically as substantial sediment masses accumulated behind major dams mostly built in the last half-century. The large scale of this sedimentary perturbation, and of the resulting deposits, reflects the order-of-magnitude change of sediment erosion, transport and deposition across the Earth's surface driven by human activities related to agriculture, construction and mineral extraction (Wilkinson 2005, Hooke et al. 2012, Zalasiewicz et al. 2016b).

Not all the signals that may be used to help to trace an Anthropocene boundary within these deposits are clear-cut. The (substantial) carbon isotopic shifts that reflect the increase in greenhouses gases noted by Finney and Edwards (2016) have indeed been changing for more than a century. Nevertheless, they show a clear mid-20 ${ }^{\text {th }}$ century inflection (Waters et al. 2016, Fig. $5 \mathrm{C}$ ), and they are only one part of a wider array of proxy signals (see below) that may be used to constrain a mid- $20^{\text {th }}$ century boundary.

\subsubsection{Temporal scale}

The critique related to the geological brevity of the Anthropocene so far has argued that "with 1945 as the beginning, it would be a geologic time unit that presently has a duration of one average human life span" (Finney and Edwards 2016).

Although much evidence points towards the mid$20^{\text {th }}$ century as the optimal beginning of any stratigraphically defined Anthropocene interval (Wolfe et al. 2013, Rose 2015, Waters et al. 2016), we emphasize that where to place the lower boundary of the Anthropocene has yet to be finalized. Thus the statement by Finney and Edwards that "Zalasiewicz et al. (2015), co-authored with 25 other members of the AWG, sets a GSSA (Global Standard Stratigraphic Age) for the Anthropocene as 1945" does not reflect that paper's actual content. The suggestion of using 1945 as a pos- 
sible lower boundary was not a formal proposal, being clearly presented as a contribution to open discussion about where, and how, the boundary might be placed. Earlier start dates have also been seriously proposed and, while remaining under consideration (Smith and Zeder 2013, Ruddiman et al. 2015, Lewis and Maslin 2015), do not on current evidence constitute optimally effective chronostratigraphic boundaries (Waters et al. 2014, Zalasiewicz et al. 2015a, b). Nonetheless, a lower boundary in the mid- $20^{\text {th }}$ century would confer upon the Anthropocene a duration of $\sim 70$ years, which is some two orders of magnitude shorter than the Holocene, and indeed comparable to one human life span.

However, the key issue in determining whether or not the Anthropocene has begun is not how long epochs are, but whether the geological record that allows characterization and correlation of the Anthropocene is already sufficiently distinct and whether its distinctive features and their stratigraphic consequences will persist for at least many millennia. The lengths of previously defined geological epochs are highly variable, for example in the Cenozoic Era alone ranging from more than 20 million years for the Eocene, to less than 12,000 years for the Holocene. Beginning with the Pliocene, epochs become successively shorter. To a large extent this reflects the increasing resolution of the geological record as one approaches the present, and a formally defined Anthropocene would simply continue this trend - with the important caveat that there would have to be firm arguments that the stratigraphic signals evident today (regardless of the future trajectory of geological history) will likely persist over geological timescales.

Put another way, the most important question with respect to duration becomes: even if all anthropogenic forcings ceased tomorrow, would the defining characteristics of the present stratigraphic signal continue to be detectable in geological strata? That is, in addition to the unique attributes of the stratigraphic record already identified and documented, has the stratigraphic record been set on an irreversible trajectory? The answer is clearly yes.

For example Earth's biota has already been transformed irreversibly. As a result, the fossil signal - important in characterizing all of the past Cenozoic, and earlier, epochs - is already, and will permanently be, distinctly representative of the Anthropocene (Barnosky 2014, Wilkinson et al. 2014, Williams et al. 2015, 2016). Distinctive fossil features include altered biological communities evident in the form of biotic homogenization caused by tens of thousands of spe- cies being transported around the globe (McNeely 2001). It is observable in, for example, the nascent fossil record of shelly marine invertebrates in coastal depositional environments, in fish faunas and invertebrates in many of the world's rivers and lakes, and in plant macrofossil and palynological records in terrestrial basins of deposition. The presently accumulating stratigraphic record is already reflecting such phenomena as the large predominance of domesticated species (especially livestock), elimination of large predators from most terrestrial and many marine environments, and widespread replacement of native floras with crop or garden species (Williams et al. 2015, 2016). These trends began thousands of years ago, but accelerated in rate and magnitude globally and recognizably in the mid- $20^{\text {th }}$ century.

The elapsed and detectable stratigraphic changes associated with a possible base of the Anthropocene in the mid- $20^{\text {th }}$ century are globally distributed and comparable to, or exceed in scale (Waters et al. 2016), equivalent signals associated with the advent of the Holocene and with those related to proposed subdivisions of the Holocene (Walker et al. 2012). They represent a physical reality that is considerably more than "minimal" or "negligible". Observational records may indeed have greater resolution than, and complement, the stratigraphic record over the past few decades, but the stratigraphic record is not "marginal" or "impoverished" particularly when compared directly with other parts of the geological column. It is the diversity and quantity of proxy signals within this stratigraphic record, reflecting recent environmental change, that are being collated by the AWG, as a prelude to the preparation of a formal proposal on the Anthropocene.

Finally, geologically brief events can leave widespread geological traces, such as the centimetre-scale iridium anomaly present in a clay layer, the base of which marks the K-Pg boundary, now recorded at some dozens of localities around the world (Schulte et al. 2010). The boundary clay was probably deposited in days, typically as an exceedingly thin layer, but the associated biotic turnover and crises in many groups of organisms was permanent. To date, 70 years for the Anthropocene is a geologically brief duration so far. Yet, 70 years after the K/Pg bolide impact, it would have been clear to any hypothetical observer then present that the world had undergone a radical biospheric shift relative to its latest Mesozoic state. Although the details, or even the broad brush, of what was to become the new Paleocene Epoch, let alone the Paleogene Period and Cenozoic Era, could not be foreseen 
at that point, the dramatic - and abrupt - change from what had come before would have already been apparent: much as where we stand today, looking back at the typical Holocene. Such playful yet instructive analogies for the Anthropocene are not limited to the Cretaceous; other pronounced boundaries in the Geological Time Scale, such as at the beginning of the Eocene, are owed to geologically brief events having protracted and frequently irreversible consequences. We suggest that, in these key regards, the Anthropocene is no different, rendering the "brevity argument" largely moot.

\subsubsection{Anthropocene cannot be consistently recognized or correlated}

It has been suggested that the Anthropocene is not consistently recognizable or is ambiguous in stratigraphical expression, with implications for its practicality in correlation (Edwards 2015; see also Autin and Holbrook 2012). For instance, the Crawford Lake (Ontario, Canada) example of Edwards (2015) shows a sediment record spanning eight centuries, with the distribution of maize (Zea mays) pollen and corn smut spores, both irregularly distributed through the core, with several possible levels shown where an Anthropocene boundary might be drawn. However, as is the case for most sedimentary sequences associated with any geological boundary, one would not expect all proxies to precisely coincide with a given boundary just as the Rhuddanian/Aeronian stage boundary of the Silurian (to take one of many examples) can be recognized by certain graptolite species (Melchin et al. 2012), but not by using chitinozoans, the assemblages of which are essentially unchanged across the boundary (Vandenbroucke, pers. comm. 2016). With respect to Crawford Lake, additional proxies not shown by Edwards do indeed record marked changes in the $20^{\text {th }}$ century driven by regional land-use changes (Ekdahl et al. 2004, 2007; Figure 4 herein), of comparable or greater magnitude than those associated with maize, which reflect sporadic occupation by pre-European indigenous peoples. Other proxies that might be recovered from the Crawford lake strata (bomb-produced radionuclides, or pesticide residues, or fly ash particles, or microplastics, for instance) would likely provide additional unambiguous evidence of stratigraphic change ascribable to the Anthropocene.

Edwards (2015) also noted the complexity of Anthropocene structures and sediments in time and space. We agree that there is great complexity locally in Anthropocene deposits, just as there is in some older deposits (for instance successions formed in caves, and in ice-marginal or volcanic settings). Yet these older deposits have not been excluded from stratigraphic analysis because of their complexity.

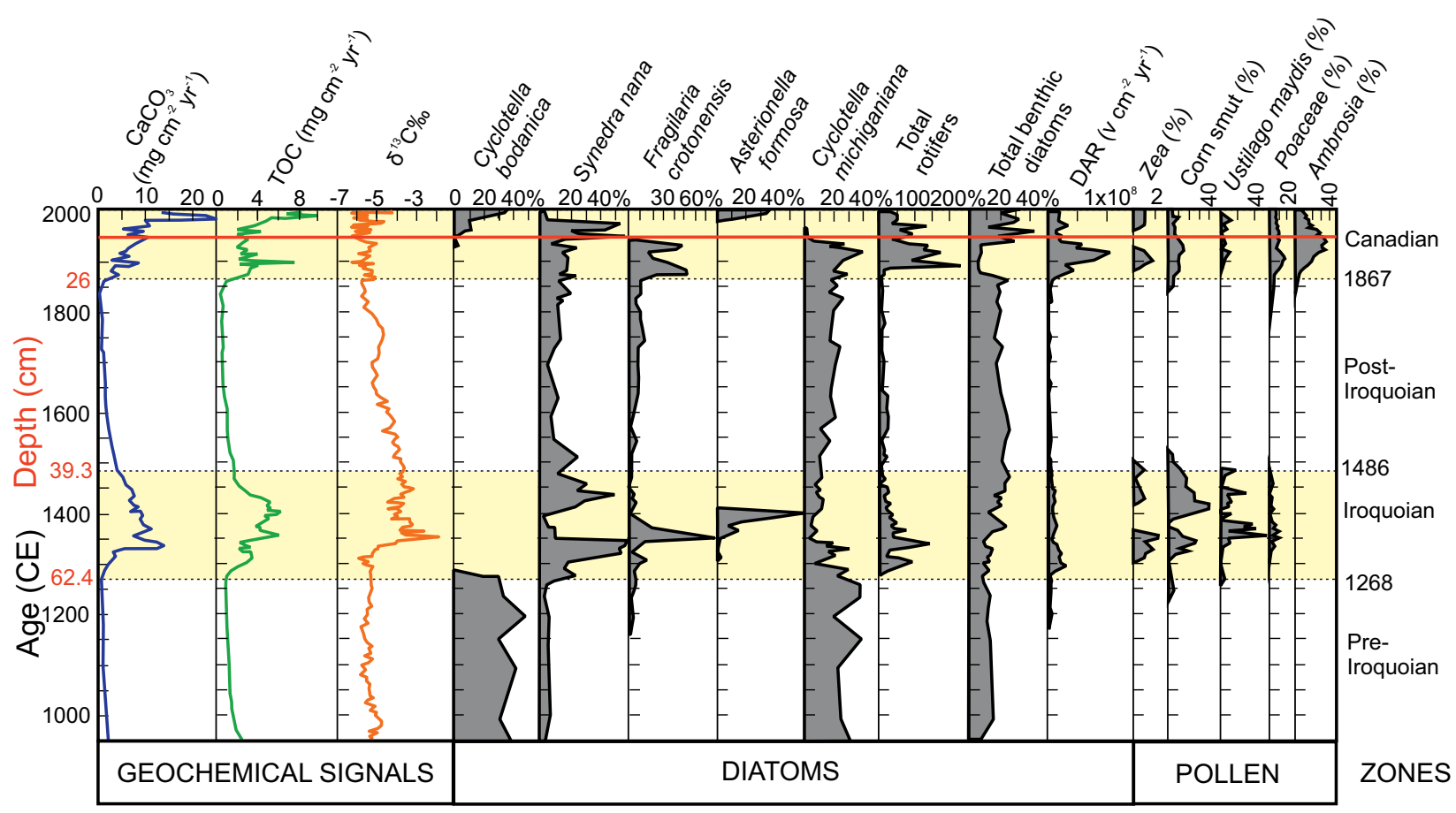

Fig. 4. Stratigraphic signals of the last millennium in Crawford Lake. The horizontal red line near the top is the $\sim 1950$ level, marked by both lithological and biostratigraphic changes in available data. Modified after Ekdahl et al. (2004). 


\subsection{The Anthropocene is based upon human observation rather than geological evidence}

\subsubsection{Anthropocene as a product of the observational record}

It has been suggested that "The concept of the Anthropocene did not derive from the stratigraphic record" and "The documentation and study of the human impact on the Earth system are based more on direct human observation than on a stratigraphic record" (Finney and Edwards 2016).

In exploring the Anthropocene concept, we have been uniquely aided by the overlap of geological and historical time and by access to detailed instrumental records. However, we emphasize that it is the stratigraphic, not the observational, case for the Anthropocene that is being evaluated by the AWG, and that this evaluation is centrally based on the accumulated sedimentary record (Zalasiewicz et al. 2011). The emerging evidence derives from a range of stratigraphic indicators that characterize a distinctive body of strata. In addition to the many examples given above, Waters et al. (2016; and see references therein), discuss:

- a range of lithostratigraphic changes associated with urbanization, agriculture, large-scale landscape modification, mineral extraction and other activities, producing substantial sedimentary bodies that are already being delineated on geological maps

- a range of distinctive components, many novel, within those strata, such as plastics (now widely dispersed in the sediments of both terrestrial and marine realms, Fig. 3E, F and L), metals and novel 'geomaterials' such as concrete

- a wide range of chemical signals including those related to a perturbation of the carbon cycle that is now likely larger than any other in the Quaternary (atmospheric $\mathrm{CO}_{2}$ increases recorded in polar ice strata (Fig. 2A), a substantial carbon isotope anomaly (Fig. 2B) - the Suess effect - recorded in organic and carbonate sediment components)

- globally distributed fly ash in diverse sedimentary successions)

- lacustrine records of a perturbation of the nitrogen cycle larger and more abrupt than that of the carbon cycle

- a range of persistent, widely detectable organic pollutants such as pesticides, industrial chemicals and products of waste combustion; globally distributed artificial radionuclides (Fig. 2B)
- and a wide range of biological changes associated with a sharply elevated extinction rate and transglobal species invasions, the latter on a scale without geological precedent.

Other indicators include substantial subsurface modifications related to mining, drilling and other activities extending to several kilometres below the surface. Thus a host of signals represents direct geological evidence of growing human impact as a key emergent influence on the course of recent Earth history. There is no reason to treat these modern successions differently than the rest of the geological column. Chronostratigraphy continues to the present, rather than stopping at some arbitrary point in the geological past.

\subsubsection{Are interpretive time scales necessary in historically recent time?}

Critics of the formalization of the Anthropocene also pose the question: "Why use interpretative time-scales when direct observations are available?" (Finney 2014). Thus, if we can now observe and record the global changes taking place, rather than infer them from the geological record, why is the corresponding stratigraphy still important and deserving of formal incorporation into the Geologic Time Scale? While it is true that observational records are ever more detailed and powerful as descriptors of Earth processes, the significance of the Anthropocene lies in the fact that those observations and recordings are tied into, and gain their context and meaning from, the entire history of the Earth, as inferred from the stratigraphic proxies preserved within rocks (and other geological archives such as glacial ice). The stratigraphic proxies within Anthropocene strata contribute directly to identifying and calibrating this most recent phase of Earth history. It is the comparison of the nature and rate of change of these proxies with those in earlier geological time, as codified in the Geological Time Scale, that enables assessment of the Anthropocene on a planetary scale.

\subsubsection{Does the Anthropocene represent geologic or historic time?}

The answer is both. The Holocene and its antecedent, the "Recent" as defined by Lyell, has always included the present. The Holocene Epoch is a formally recognized geochronologic unit defined currently only by its base. Geological time by implication therefore extends to the present day. The Anthropocene, in comprising the last $\sim 70$ years of what is presently the Holocene, occupies the overlap between geological, historical 
and instrumental time. This unique feature of the Anthropocene allows, and indeed logically demands, that geological, historical, and instrumental evidence be tightly interlinked.

\subsection{Chronostratigraphic units need not be linked to major Earth System changes}

It has been observed that “... many, if not most, of the ratified GSSPs are at stratigraphic levels that do not represent major changes to the Earth System, whether geologic or biologic. For example, the bases of the Ordovician, Devonian, Carboniferous, and Permian systems are placed at the lowest occurrences of single graptolite or conodont species" (Finney and Edwards 2016).

This contention may be true of many stages/ages, but it misses an important facet of the formulation of chronostratigraphic units. The criteria used to justify why one system, series or stage is different from another, and warrants a distinct name, is not simply a case of the new appearance of, for example, a single distinctive fossil taxon: if so, there would be a plethora of chronostratigraphic units coinciding with such events. More commonly, although the lowest occurrence of a single taxon or other stratigraphic marker is typically specified as marking a chronostratigraphic boundary, contemporaneously there are fundamental changes to biotic assemblages as a whole, and/or to ocean and/or atmospheric chemistry, and sometimes even to continental configurations and oceanic circulation. More rarely, as in the case of the Cretaceous-Paleogene boundary (Molina et al. 2006), the biotic changes reflect overwhelming extraterrestrial influence.

For instance, the GSSP for the Permian System, located at Aidaralash Creek, northern Kazakhstan, is placed at the lowest occurrence of the conodont Streptognathodus isolatus (Davydov et al. 1998). But the recognition of the Permian System is a reflection of a transition to an arid climate, reduction in coal swamps and development of major evaporites. In fact, Murchison (1841) originally defined the base of the Permian in the Ural Mountains, Russia, to coincide with strata marking the onset of evaporite deposition.

Likewise, arguments against the Anthropocene have advanced as follows: "The evolution of vascular land plants and their spread across the continents from late in the Devonian to early in the Permian completely altered Earth's surface, left a significant stratigraphic record, and dramatically altered $\mathrm{CO}_{2}$ and $\mathrm{O}_{2}$ concentrations in the atmosphere and oceans to extents far beyond what humans are projected to do (Berner and
Canfield 1989, Berner 1998). Yet there is no drive to name a unit in the ICS Chart that formally recognizes that profound and irreversible change to the Earth System" (Finney and Edwards 2016). Such arguments miss a key connection between stratigraphic change and Earth System change. In this case, the Carboniferous is named after the coal deposits that resulted from the vegetational change that was triggered by an Earth System change and in fact does "formally recognize that profound and irreversible change to the Earth system" - even to the extent of inserting the plantproduced carbon into the name of the unit. This case also illustrates the problems that can result when single-species appearances are considered independently from the processes that drive the biotic reorganizations. It is true that the base of the Carboniferous System is currently defined in a GSSP in Montagne Noire (France) by the lowest occurrence of the conodont Siphonodella sulcata (Paproth et al. 1991), and that the characteristic diversification of land plants does not form an intrinsic part of that formal definition. However, subsequent investigations have identified serious problems with this boundary, leading Davydov et al. (2012) to state "all these new data result in issues that affect not only the Carboniferous time scale but also the GSSP concept". The second revision of that GSSP is currently the focus of a new international working group, and strong consideration is being given to basing the boundary on the global Hangenberg Crisis (Becker et al. 2016). During that event, complete ecosystems were destroyed (e.g., all reefs and early forests) or profoundly modified (e.g. the lowland terrestrial ecosystems and the outer shelf marine habitats), with the major biotic overturn instigated by sudden climatic changes, sea-level fluctuations, and the spread of hypoxia/anoxia during a short-lived change from global greenhouse to icehouse conditions (Becker et al. 2016). Such a fundamental Earth System event and its attendant stratigraphic signals would appear to be better suited to position the base of such a significant interval of Earth history than the evolution of a single conodont species, the nature and location of which have proved problematic.

\subsection{Chronostratigraphic units should not be defined solely by their beginning}

It has been suggested that: "Regrettably, focusing on the definition of the beginning of the Anthropocene can result in the lack of consideration of its stratigraphic content and its concept. It conveys the opinion that 
units of the Geologic Time Scale are defined solely by their beginnings, rather than their content" (Finney and Edwards 2016).

This statement seems to refer to a publication (Zalasiewicz et al. 2015a) suggesting a mid- $20^{\text {th }}$ century beginning for the Anthropocene. However, that paper clearly referred to stratigraphic content both below and above any proposed boundary, an approach that was further developed in Waters et al. (2016) in order to show the stratigraphic trends and patterns of the Anthropocene in the context of centennial to multi-millennial scales, without a priori consideration of where the boundary should be placed. The focus on defining the base of a chronostratigraphic unit is a fundamental aspect of the GSSP approach. All chronostratigraphic units, to become formalized, require definition of their base and so the approach taken by the AWG does not differ from that taken elsewhere in the geological column. That the GSSP approach does not give adequate consideration of the content of the unit compared with 'body stratotypes' is a criticism that has resulted in the suggestion to consider 'unit stratotypes' (Hilgen et al. 2006). Despite the problems intrinsic to the GSSP approach, as outlined by Smith et al. (2014), we agree that this is the approach within which any proposal has to be formulated.

\subsection{The Anthropocene is in large part dependent upon future scenarios}

\subsubsection{The Anthropocene is based upon predictions}

This concern has been expressed as if the stratigraphic records of the Anthropocene "are based on predictions that might appear in the future" leading to the inference that "it is the present and future versus the past." (Finney and Edwards 2016).

We note here that the case being made for the Anthropocene rests solely on evidence documented within existing strata that represent past events, as it must. Deposits representing the Anthropocene, such as 'madeground', are not imagined future deposits, but existing physical units that can be depicted on geological maps both of the past (e.g. Suess in $19^{\text {th }}$ century Vienna) and the present (British Geological Survey maps).

With respect to the geological longevity of these elapsed events, Anthropocene deposits have similar preservation potential to the strata of the Holocene, and indeed to the strata representing all other epochs. Many terrestrial deposits, especially of upland areas, will be eroded, while a large part of the marine record will be preserved. In the intervening coastal realm, deposits on subsiding crust (e.g. many large delta tops) have considerably better preservation potential than those on long-term tectonically rising crust. Many Anthropocene markers in the geological record are likely to be even longer-lived and more evident than key markers for other geological units. For example, the Greenland and Antarctic ice sheets, which include excellent high-resolution records for both the Pleistocene and Holocene (and, on Greenland, include the Holocene Series GSSP and prospective Middle Holocene Subseries GSSP), will be geologically relatively short-lived even if human-driven global warming is arrested. Erosion of most unmodified Holocene deposits will result in geologically unremarkable successor (derived) deposits, whereas erosion of many Anthropocene terrains, especially the many thousands of square kilometres of urban and agricultural areas (among the regions where Holocene deposits have already been extensively reworked) will produce deposits that have distinctive lithological and geochemical features reflecting the extensive novel materials being eroded (e.g. Poirier et al. 2011).

\subsubsection{The major anthropogenic impacts may lie ahead}

A related argument has been formulated as follows: we do not know the full extent of anthropogenic impact; more serious impacts lie ahead, that may lead to erascale change (Gibbard and Lewin 2016) and thus it is better practice to wait until the full effects are clearer (Wolff 2014, Smil 2015).

Waiting until fuller effects become clear would be in essence an appeal to the future, a path we are trying to avoid in documenting extant geologic evidence for an Anthropocene epoch. Recently elapsed (and in part irreversible) changes already imprinted on the stratigraphic record provide reasonable evidence that epoch-scale change has now taken place (Waters et al. 2016). This change, encapsulated in the term 'Anthropocene', already forms part of current debate and study in the Earth sciences and in other disciplines. As a geological entity, the Anthropocene epoch possesses both a narrative and a stratigraphy commensurate with prior subdivisions of Earth history: major changes in planetary dynamics have occurred, and their geological legacy has been identified as a suite of materials that can be mapped and correlated.

\subsubsection{Future natural events may be of greater magnitude}

A further variation of this critique is: The effects of human-made changes to the stratigraphic record may 
be easily obliterated by subsequent larger events, such as volcanic outbursts or asteroid impacts (Visconti 2014).

Again, this is an appeal to the future consequences of possible trajectories of Earth history rather than to geological evidence. The Geological Time Scale is constructed from well-characterized stratigraphy to provide utility for the current generation of geologists. In any case, taking the critique at face value, even cataclysmic events such as an asteroid impact or supervolcano eruption will be highly unlikely to obliterate any existing stratigraphic record of global extent, including that of the Anthropocene.

Thus, in the Phanerozoic, only one isolated asteroid is known to have markedly changed the course of Earth history, when it hit the Yucatán Peninsula (Mexico) to precipitate termination of the Cretaceous (Schulte et al. 2010). Smaller events, such as the Miocene Ries impact crater in Germany (Stöffler et al. 2002), seem to have had only regional effects. Volcanic activity on various scales will occur in the future as it has occurred in the past, up to and including super-eruptions such as those at Yellowstone, and Large Igneous Provinces, capable of altering climate and ocean chemistry. They can create their own history, but do not necessarily 'obliterate' previous histories. The converse often occurs: examples of histories spectacularly preserved by volcanic outbursts include the Silurian Herefordshire lagerstätte (Briggs et al. 2016), some of the earliest conifers with preserved vascular structure in the Carboniferous (Galtier et al. 1992), fossil Eocene wood in kimberlites (Wolfe et al. 2012), Miocene vertebrates entombed in Yellowstone-derived distal ash layers (Voorhies and Stover 1978), and indeed Pompeii and Herculaneum in Roman times.

\subsection{The Anthropocene lacks utility as a stratigraphic term}

This criticism has been expressed as follows: it is unclear how demarcation of the Anthropocene enhances our understanding of the anthropogenic record (Walker et al. 2015).

The Anthropocene, as proposed by Crutzen and Stoermer (2000) and characterized stratigraphically by Waters et al. (2016) and in allied publications, represents a distinct, major and (in important respects) irreversible phenomenon: a marked change in the Earth System with a distinctive stratal record. As such, the term Anthropocene helps enable wide and effective communication of this concept and of the material record. Consistency of communication would be helped by precise definition of the term, and becoming part of the International Chronostratigraphic Chart would stabilize its meaning yet further.

For the geological community, a key consideration in formalization of the Anthropocene is stratigraphic reality and distinctiveness, and in this respect we suggest that a good case can be made. Recognizing the Anthropocene formally communicates the reality of the present phase of geological history and process; conversely, not doing so masks an event in Earth history of a magnitude at least equal to the changes that triggered many previous transitions from one epoch to the next. This event is most clearly, globally and synchronously expressed from the mid- $20^{\text {th }}$ century onwards, and characterizing such a stratigraphic Anthropocene - whether formal or informal - would seem to serve the purpose of facilitating precise communication within the Earth and related sciences. The term is indeed already widely employed, and formalization may have the advantage of facilitating more precise usage.

\subsection{The Anthropocene is a political or cultural rather than scientific construct}

\subsubsection{The Anthropocene is a historical event}

This concern has been expressed as "The Anthropocene is a unit of human history, not Earth history" (Finney 2014) and is therefore "of similar character to the term Renaissance" (Finney and Edwards 2016).

This is an important point because it highlights the fact that different people use the term "anthropocene" (lower-case) in reference to entirely different concepts. The significance of the ICS International Chronostratigraphic Chart is that it provides an unambiguous definition of the geological column, and provides a common language that scientists can use consistently. This emphasizes the importance of clearly defining what (upper-case) "Anthropocene" means in a strict, geological (and Earth System) sense and contrasting that with more general usages. By comparison, the Renaissance represents a series of changes exclusively in human culture and history, starting in Italy, then spreading throughout much of Europe. Its discussion and study is detached from geology and from wider changes to the Earth System occurring at the time or to any distinctive stratal signatures then produced. The stratigraphic Anthropocene, in contrast, is founded on substantial changes to the Earth System that are re- 
flected by an array of stratigraphic signatures, as noted above and elaborated elsewhere (e.g. Waters et al. 2016). It so happens that the bulk of this change is currently human-driven, but if exactly the same changes had been produced not by human action, but for example by actions of some other species, by the effect of extraordinary volcanic eruptions or bolide strikes, or by some other means, then the geological justification would remain unchanged.

Similarly, the Atomic Age (see Finney and Edwards 2016) is a term coined to describe the beginning of a particular phase or mode of human history, with an accent first on military capabilities, with later emphasis on possible civilian uses of nuclear power. The significance to stratigraphy is via the resultant global, precisely correlatable signal within sediments worldwide (Waters et al. 2015), largely from atomic bomb tests (e.g. sediment inventories of ${ }^{14} \mathrm{C},{ }^{137} \mathrm{Cs},{ }^{239+240} \mathrm{Pu}$ and $\left.{ }^{241} \mathrm{Am}\right)$. This is arguably a sharper signal than those directly provided by larger drivers of current stratigraphic change (e.g. carbon cycle perturbation), but it does not follow that it should be adopted for the name of the time interval, any more than the akidograptid graptolites chosen to define the base of the Silurian Period (Rong et al. 2008) should be used in re-naming that period.

\subsubsection{The Anthropocene is a cultural diachronous event}

The concern has been further developed: "Furthermore, it would be contrary to define its (the Renaissance's) beginning at a single point in time because it is a cultural movement that is not tied to a single date. The same is true of the Anthropocene." (Finney and Edwards 2016).

Most GSSPs have been chosen strategically at points that are part of some complex evolving continuum, which in reality was not tied to a single date or place. This is no different from, for example, proposing to select the start of the Renaissance at year 1401, when Lorenzo Ghiberti beat Filippo Brunelleschi to a contract to build bronze doors for the Florence Baptistery (Walker 2003). For instance, the base of the Cambrian was chosen at a rock stratum where a particular type of burrow (named Treptichnus pedum) was considered to first appear in a rock section in Newfoundland (Landing 1994). This represents the origin of an important general phenomenon (bioturbation of the sea floor) - but it only generally represents this phenomenon, as T.pedum (which is not unproblematic taxonomically) represents only one component (and not even the earliest) of an evolving plexus of burrowing organisms that lived during the late Ediacaran and early Cambrian, so that its appearance can at best only represent its earliest immigration to that specific locality on the former sea floor. In that case, the inference was made prematurely because T.pedum was subsequently found lower in the section, although the GSSP remains where it had been originally sited. At the Silurian GSSP at Dob's Linn in Scotland, the GSSP is marked where the planktonic species Akidograptus ascensus was first found in the section (Rong et al. 2008). Again, this is a local immigration, albeit of an oceanic organism that was part of an evolving lineage of which only parts have been captured worldwide. Yet in practice, both of these GSSPs continue to function reasonably well despite these limitations (although see Babcock et al. 2014). As documented so far in the peer-reviewed literature (e.g. Wolfe et al. 2013, Rose 2015, Waters et al.2016), the large array of widespread stratigraphic indicators associated with the Anthropocene is likely to allow adequate definition and correlation of a chronostratigraphic boundary: one that represents the most abrupt and widely correlatable event in a continuum of human influence on the Earth System - no less effectively, indeed, than the definition of earlier epochs by their corresponding indicators.

\subsubsection{The Anthropocene is a political statement}

Whether the Anthropocene is political or scientific has been most expressly questioned by Finney and Edwards (2016), for instance when stating that "the drive to officially recognize the Anthropocene may, in fact, be political rather than scientific"; and "we address the question of whether or not the International Commission on Stratigraphy is being asked to make what is in effect a political statement". Closely related to this is the suggestion that the Anthropocene is a phenomenon not of geology but of pop culture (Autin and Holbrook 2012).

While the Anthropocene as a term cannot escape 'public and political resonance' (Gibbard and Lewin 2016), it is essential that the case for a formal stratigraphic Anthropocene unit rests upon stratigraphic evidence, as explained throughout this article. The exceedingly wide array of stratigraphic signals underpinning it demonstrates that it encompasses a real and distinctive time interval recognizable by its stratigraphic record.

Indeed, much of the controversy about whether defining the Anthropocene is scientifically and strati- 
graphically based or political is driven by the imprecision with which the term is used by various communities. Thus, it is important to specify what the term means precisely in the context of its geological usage whether or not the ultimate decision is to formally recognize the Anthropocene as an epoch.

It is clear that many of the phenomena connected with the Anthropocene are of societal, and hence political, importance. However, this does not mean that they cannot be treated objectively and scientifically analyzed, within the appropriate - in this case formal stratigraphic - framework.

\subsubsection{Humans are not alone in affecting the environment}

A related criticism has been made: "All organisms impact the environment, so it is anthropocentric to suggest that we are special" (Walker et al. 2015, Baskin 2015) in this regard.

All organisms alter their environments, and in some important ways it is the activities of some of the simplest organisms that have the most fundamental influence: earthworms move very large amounts of soil, for instance, and microbes are centrally involved in the geochemical cycles that maintain the Earth System. In this context it is the scale, nature, pace and novelty of human impact that is significant to the Anthropocene, and not the fact that humans are currently the main driving force of change. The rapid, major perturbations to the geochemical cycles, biological communities and sedimentation as detailed above represent important events on the planetary scale, regardless of cause. Indeed, if this same array of phenomena had some cause other than human impact, its importance to stratigraphy would be no lesser - but it may have been in some ways easier to analyze and categorize.

\section{Outlook}

The Anthropocene Working Group, of which all authors of this article but one (FG) are members, has carried out an initial exploratory phase of its analysis, in collating evidence from various sources to assess whether a case can be made to justify a formal proposal to add the Anthropocene to the International Chronostratigraphic Chart. This evidence, outlined in a number of publications since the establishment of the AWG (see Waters et al. 2016 and references therein) was considered sufficient by the AWG to allow the construction of a formal proposal, on which work is now in progress. This analysis, though, has attracted a range of commentary, including some criticism. Here we have taken the opportunity to summarize our responses to arguments that have been made against the Anthropocene as a potential formalized unit in chronostratigraphy/geochronology. We see this process of appraisal of and response to such commentaries as a fundamental part of the process by which the AWG can more effectively build a case for formalization.

Critical commentary has been helpful in guiding the research activities of the AWG. One of the clearest examples of this relates to the suggestion in Zalasiewicz et al. (2015a) that a GSSA of 1945 for the start of the Anthropocene may provide a practical solution. Subsequent commentary has clearly indicated that the stratigraphical community in general, but ICS in particular, prefer the AWG to follow a GSSP route as is the most familiar and widely accepted method of defining geological time units. Hence, work is beginning to identify and select candidate GSSP sites in likely sedimentary or novel environmental settings (such as anoxic marine basins, lakes, polar ice, annually banded corals, speleothems, tree rings and so on). The process of investigating the nature of proxy signals within these environments is anticipated to greatly improve our understanding of the expression of the Anthropocene as a globally correlatable event. Once this work has been completed, in the next few years, it is planned to make a formal proposal regarding the Anthropocene, to the Subcommission on Quaternary Stratigraphy and, if approved by that body, to the full ICS and then the Executive Committee of the IUGS.

\section{Conclusions}

The Anthropocene, as an emerging concept in stratigraphy, has attracted much discussion, including a body of critical commentary. That commentary requires careful consideration as part of any process of potential formalization. Accordingly, the major criticisms of a formalized Anthropocene are analyzed here. Once certain misunderstandings are clarified, we show that none of the criticisms as proffered provides significant geological basis for denying its incorporation into the Geological Time Scale.

On the contrary, a good case can be made that the character and scale of its extant stratigraphy already warrants recognition of the Anthropocene as a formal unit of the Geological Time Scale, and work is proceeding to prepare a formal proposal. 
Acknowledgements. This paper is a contribution of the Anthropocene Working Group. Colin Waters publishes with the permission of the Executive Director, British Geological Survey (BGS), Natural Environment Research Council, funded with the support of the BGS's Engineering Geology science program. This research received no other specific grant from any funding agency in the public, commercial, or not-for-profit sectors.

\section{References}

Astibia, H., 2012. Tunelboka y Gorrondatxe (Getxo, Bizkaia), fósiles humanos para el Antropoceno. Euskonews, $640,1-11$.

Autin, W. J., Holbrook, J. M., 2012. Is the Anthropocene an issue of stratigraphy or pop culture? GSA Today 22(7), 60-61, doi:10.1130/G153GW.1.

Babcock, L.E., Peng, S., Zhu, M., Xiao, S., Ahlberg, P., 2014. Proposed reassessment of the Cambrian GSSP. Journal of African Earth Sciences 98, 3-10.

Barnosky, A. D., 2014. Palaeontological evidence for defining the Anthropocene. In: Waters, C.N., Zalasiewicz, J. A., Williams, M., Ellis, M. A., Snelling, A. M. (eds.), A Stratigraphical Basis for the Anthropocene. Geological Society, London, Special Publications 395, 149-165.

Baskin, J., 2015. Paradigm Dressed as Epoch: The Ideology of the Anthropocene. Environmental Values 24, 9-29.

Becker, R. T., Kaiser, S. I., Aretz, M., 2016. Review of chrono-, litho- and biostratigraphy across the global Hangenberg Crisis and Devonian-Carboniferous Boundary. In: Becker, R. T., Königshof, P., Brett, C.E. (Eds.), Devonian Climate, Sea Level and Evolutionary Events, Geological Society London, Special Publications 423. http://doi.org/ 10.1144/SP423.10

Berner, R.A., 1998. The carbon cycle and carbon dioxide over Phanerozoic time: the role of land plants. Philosophical Transactions of the Royal Society B: Biological Sciences 353, 75-82.

Berner, R. A., Canfield, D.E., 1989. A new model for atmospheric oxygen over Phanerozoic time. American Journal of Science 289, 333-361.

Berry, E. W., 1925. The term Psychozoic. Science 44, 16.

Braje, T.J., 2016. Evaluating the Anthropocene: Is there something useful about a geological epoch of humans? Antiquity 90, no. 350, 504-512.

Briggs, D.E. G., Siveter, D.J., Siveter, D.J., Sutton, M.D., Legg, D., 2016. Tiny individuals attached to a new Silurian arthropod suggest a unique mode of brood care. Proceedings of the National Academy of Sciences of the U.S.A., 113, 4410-4415.

Corcoran, P.L., Moore, C. J., Jazvac, K., 2014. An anthropogenic marker horizon in the rock record. GSA Today 24(6), 4-8.

Crutzen, P. J., 2002. Geology of Mankind. Nature 415, 23.

Crutzen, P.J., Stoermer, E.F., 2000. The Anthropocene. Global Change Newsletters 41, 17-18.
Davies, J.R., Fletcher, C.J.N., Waters, R.A., Wilson, D., Woodhall, D. G., Zalasiewicz, J. A., 1997. Geology of the country around Llanilar and Rhayader. Memoir of the British Geological Survey, Sheets 178 \& 179 (England and Wales), xii + 267 pp.

Davydov, V.I., Glenister, B.F., Spinosa, C., Ritter, S.M., Chernykh, V.V., Wardlaw, B.R., Snyder, W.S., 1998. Proposal of Aidaralash as Global Stratotype Section and Point (GSSP) for base of the Permian System. Episodes 21(1), 11-18.

Davydov, V.I., Korn, D., Schmitz, M. D., 2012. Chapter 23: The Carboniferous Period, In: Gradstein, F.M., Ogg, J.G., Schmitz, M., Ogg, G. (Eds.), The Geologic Time Scale 2012. p.603-651. Elsevier B.V.

Edgeworth, M., Richter, D. deB., Waters, C.N., Haff, P., Neal, C., Price, S.J., 2015. Diachronous beginnings of the Anthropocene: The lower bounding surface of anthropogenic deposits. Anthropocene Review 2(1), 1-26.

Edwards, L.E., 2015, What is the Anthropocene? Eos, https://eos.org/opinions/what-is-the-anthropocene

Ekdahl, E. J., Teranes, J.L., Guilderson, T.P., Turton, C. L., McAndrews, J.H., Wittkop, C. A., Stoermer, E. F., 2004. Prehistorical record of cultural eutrophication from Crawford Lake, Canada. Geology 32, 745-748.

Ekdahl, E. J., Teranes, J.L., Wittkop, C.A., Stoermer, E. F., Reavie, E.D., Smol, J.P., 2007. Diatom assemblage response to Iroquoian and Euro-Canadian eutrophication of Crawford Lake, Ontario, Canada. Journal of Paleolimnology 37, 233-246.

Falkowski, P., Scholes, R.J., Boyle, E., Canadell, J., Canfield, D., Elser, J., Gruber, N., Hibbard, K., Högberg, P., Linder, S., Mackenzie, F. T., Moore III, B., Pedersen, T., Rosenthal, Y., Seitzinger, S., Smetacek, V., Steffen, W., 2000. The Global Carbon Cycle: A Test of Our Knowledge of Earth as a System. Science 290, 291-296.

Finney, S.C., 2014. The 'Anthropocene' as a ratified unit in the ICS International Chronostratigraphic Chart: fundamental issues that must be addressed by the Task Group. In: Waters, C.N., Zalasiewicz, J.A., Williams, M., Ellis, M.A., Snelling, A.M. (eds.), A Stratigraphical Basis for the Anthropocene. Geological Society, London, Special Publications 395, p. 23-28.

Finney, S.C., Edwards, L.E., 2016. The "Anthropocene" epoch: Scientific decision or political statement? GSA Today 26(2-3), 4-10.

Foley, S.F., Gronenborn, D., Andreae, M.O., Kadereit, J.W., Esper, J., Scholz, D., Pöschl, U., Jacob, D.E., Schöne, B. R., Schreg, R., Vött, A., Jordan, D., Lelieveld, J., Weller, C.G., Alt, K. W., Gaudzinski-Windheuser, S., Bruhn, K.-C., Tost, H., Sirocko, F., Crutzen, P.J., 2013. The Palaeoanthropocene - The beginnings of anthropogenic environmental change. Anthropocene 3, 83-88.

Ford, J.R., Price, S. J., Cooper, A.H., Waters, C. N., 2014. An assessment of lithostratigraphy for anthropogenic deposits. In: Waters C. N., Zalasiewicz, J., Williams, M., Ellis, M. A., Snelling, A. (eds.), A Stratigraphical Basis for the Anthropocene. Geological Society, London, Special Publications 395, 55-89. 
Galtier, J., Scott, A.C., Powell, J.H., Glover, B. W., Waters, C.N., 1992. Anatomically preserved conifer-like stems from the Upper Carboniferous. Proceedings of the Royal Society of London 247, 211-214.

Ganopolski, A., Winkelmann, R., Schellnhuber, H. J., 2016. Critical insolation- $\mathrm{CO}_{2}$ relation for diagnosing past and future glacial inception. Nature 529, 200-203.

Gervais, P., 1867-1869. Zoologie et paléontologie générales: Nouvelles recherches sur les animaux vertébrés vivants et fossiles. Bertrand, Paris, $263 \mathrm{pp}$.

Gibbard, P., Head M.J., 2009. The definition of the Quaternary System/Period and the Pleistocene Series/Epoch. Quaternaire 20(2), 125-133.

Gibbard, P.L., Walker, M.J.C., 2014. The term 'Anthropocene' in the context of formal geological classification. In: Waters, C. N., Zalasiewicz, J. A., Williams, M., Ellis, M. A., Snelling, A. M. (eds.), A Stratigraphical Basis for the Anthropocene. Geological Society, London, Special Publications 395, p. 29-37.

Gibbard, P.L., Lewin, J. 2016. Partitioning the Quaternary. Quaternary Science Reviews 151, 127-139.

Gobeil, C., Macdonald, R. W., Smith, J.N., Beaudin, L., 2001. Atlantic water flow pathways revealed by lead contamination in Arctic Basin sediments. Science 293, 1301-1304.

Gradstein, F.M., Ogg, J.G., Schmitz, M., Ogg, G. (Eds.), 2012. The Geologic Time Scale, 1144 pp. Elsevier, Amsterdam.

Grinevald, J., 2007. La Biosphère de l'Anthropocène: climat et pétrole, la double menace. Repères transdisciplinaires (1824-2007). Chêne-Bourg/Genève: Georg Editeur/Editions Médecine \& Hygiène, coll. 'Stratégies énergétiques, Biosphère et Société'.

Hamilton, C., Grinevald, J., 2015. Was the Anthropocene anticipated? The Anthropocene Review 2, 59-72.

Hancock, G. J., Leslie, C., Everett, S.E., Tims, S. G., Brunskill, G. J., Haese, R., 2011. Plutonium as a chronomarker in Australian and New Zealand sediments: a comparison with ${ }^{137}$ Cs. Journal of Environmental Radioactivity 102, 919-929.

Head, M.J., Gibbard, P.L., 2015. Formal subdivision of the Quaternary System/Period: Past, present, and future. Quaternary International 383,4-35.

Hilgen, F.J., Brinkhuis, H., Zachsriasse, W.J., 2006. Unit Stratotypes for global stages: the Neogene perspective. Earth Science Reviews 74, 113-125.

Hooke, R. LeB., Martin-Duque, J.F., Pedraza, J., 2012. Land transformation by humans: a review. GSA Today 22,4-10.

Irabien, M.J., García-Artola, A., Cearreta, A., Leorri, E., 2015. Chemostratigraphic and lithostratigraphic signatures of the Anthropocene in estuarine areas from the eastern Cantabrian coast (N. Spain). Quaternary International 364, 196-205.

Ivar do Sul, J. A., Costa, M.F., 2014. The present and future of microplastic pollution in the marine environment. Environmental Pollution 185, 352-364.

Knoll, A., Walter, M., Narbonne, G., Christie-Blick, N., 2006. The Ediacaran Period: a new addition to the geologic time scale. Lethaia 39, 13-30.
Landing, E., 1994. Precambrian-Cambrian global stratotype ratified and a new perspective of Cambrian time. Geology 22, 179-182.

Lewis, S.L., Maslin, M.A., 2015. Defining the Anthropocene. Nature 519, 171-180.

Martinez-Boti, M.A., Foster, G.L., Chalk, T.B., Rohling, E.J., Sexton, P.F., Lunt, D.J., Pancost, R.D., Badger, M.P.S., Schmidt, D.N., 2015. Plio-Pleistocene climate sensitivity evaluated using high-resolution $\mathrm{CO}_{2}$ records. Nature 518, 49-54.

McNeely, J., 2001. Invasive species: A costly catastrophe for native biodiversity. Land Use and Water Resources Research 1(2), 1-10.

Melchin, M.J., Sadler, P.M., Cramer, B.D., 2012. Chapter 21: The Silurian Period. In: Gradstein, F.M., Ogg, J.G., Schmitz, M., Ogg, G. (eds.), The Geologic Time Scale 2012. p. 525-558. Elsevier B. V.

Molina, E., Alegret, L., Arenillas, I., Arz, J.A., Gallala, N., Hardenbol, J., Salis, K. von, Steurbaut, E., Vandenberghe, N., Zaghbib-Turki, D., 2006. The Global Boundary Stratotype Section for the base of the Danian Stage (Paleocene, Paleogene, "Tertiary", Cenozoic) at El Kef, Tunisia - original definition and revision. Episodes 29(4), 263-273.

Murchison, R.I., 1841. First sketch of the principal results of a second geological survey of Russia. Philosophical Magazine 3(19), 417-422.

Myhre, G. et al. 2013. Chapter 8: Anthropogenic and Natural Radiative Forcing. In: Climate Change 2013: The Physical Science Basis. Working Group I Contribution to the IPCC Fifth Assessment Report. Intergovernmental Panel on Climate Change (IPCC), Geneva, Switzerland. http://www.climatechange2013.org/images/uploads/WG IAR5_WGI-12Doc2b_FinalDraft_All.pdf

Nagle, R., 2008. To love a Landfill. The History and Future of Fresh Kills. In: France, R.L. (ed.), Handbook of Regenerative and Landscape Design. p.3-16, CRC Press, Boca Raton.

Paproth, E., Feist, R., Flajs, G., 1991. Decision on the Devonian-Carboniferous boundary stratotype. Episodes 14, 331-336.

Poirier, C., Chaumillon, E., Arnaud, F., 2011. Siltation of river-influenced coastal environments: Respective impact of late Holocene land use and high-frequency climate changes. Marine Geology 290, 51-62.

Revkin, A.C., 1992. Global warming : understanding the forecast (American Museum of Natural History, Environmental Defense Fund). Abbeville Press, New York, NY.

Rong, J., Melchin, M.J., Williams, S.H., Koren, T.N., Verniers, J., 2008. Report of the restudy of the defined global stratotype of the base of the Silurian System. Episodes 31, 315-318.

Rose, N. L., 2015. Spheroidal carbonaceous fly ash particles provide a globally synchronous stratigraphic marker for the Anthropocene. Environmental Science and Technology 49(7), 4155-4162.

Royer, D.L., 2016. Climate Sensitivity in the Geologic Past. Annual Review of Earth and Planetary Sciences 44. doi: 10.1146/annurev-earth-100815-024150 
Ruddiman, W.F., 2013. Anthropocene. Annual Review of Earth and Planetary Sciences 41, 45-68.

Ruddiman, W.F., Ellis, E.C., Kaplan, J.O., Fuller, D.Q., 2015. Defining the epoch we live in. Science 348, 38-39.

Salvador, A. (Ed.), 1994. International Stratigraphic Guide: A Guide to Stratigraphic Classification, Terminology, and Procedure, Second Edition. International Subcommission on Stratigraphic Classification of IUGS International Commission on Stratigraphy and The Geological Society of America, Boulder, Colorado, xix 214 pp.

Scheffold, M., 2014. Der Berliner Teufelsberg - Typuslokalität einer neuen stratigraphischen Einheit des Anthropozäns? - 48 pp., unpubl. BSc-Thesis, Fac. Geosciences, Freie Universität Berlin.

Schimmelmann, A., Hendy, I.L., Dunn, L., Pak, D.K., Lange, C. B., 2013. Revised 2000-year chronostratigraphy of partially varved marine sediment in Santa Barbara Basin, California. GFF 135(3-4), 258-264.

Schulte, P., Alegret, L., Arenillas, I., Arz, J. A., Barton, P. J., Bown, P.R., Bralower, T. J., Christeson, G.L., Claeys, P., Cockell, C.S., Collins, G.S., Deutsch, A., Goldin, T.J., Goto, K., Grajales-Nishimura, J.M., Grieve, R.A.F., Gulick, S.P.S., Johnson, K.R., Kiessling, W., Koeberl, C., Kring, D.A., MacLeod, K.G., Matsui, T., Melosh, J., Montanari, A., Morgan, J.V., Neal, C.R., Nichols, D. J., Norris, R.D., Pierazzo, E.. Ravizza, G., RebolledoVieyra, M., Reimold, W.U., Robin, E., Salge, T., Speijer, R.P., Sweet, A.R., Urrutia-Fucugauchi, J., Vajda, V., Whalen, M.T., Willumsen, P.S., 2010. The Chicxulub asteroid impact and mass extinction at the CretaceousPaleogene boundary. Science 327, 1214-1218.

Sherlock, R.L., 1922. Man as a Geological Agent: An Account of his Action on Inanimate Nature. H.F. \& G. Witherby, London.

Smil, V., 2015. It's Too Soon to Call This the Anthropocene. IEEE Spectrum 52(6), 28.

Smith, A. G., Barry, T., Bown, P., Cope, J., Gale, A., Gibbard, P., Gregory, J., Hounslow, M., Kemp, D., Knox, R., Marshall, J., Oates, M., Rawson, P., Waters, C., 2014. GSSPs, global stratigraphy and correlation. In: Smith, D. G., Bailey, R.J., Burgess, P.M., Fraser, A.J. (eds.), Strata and Time: Probing the Gaps in Our Understanding. Geological Society, London, Special Publications 404, 37-67.

Smith, B.D., Zeder M. A., 2013. The onset of the Anthropocene. Anthropocene 4, 8-13.

Smith, J.A., Andersen, T.J., Shortt, M., Gaffney, A.M., Truffer, M., Stanton, T.P., Bindscadler, R., Dutrieux, P., Jenkins, A., Hillenbrand, C.-D., Ehrmann, W., Corr, H.F. J., Farley, N., Crowhurst, S., Vaughan, D. G., 2016. Sub-ice-shelf sediments record history of twentieth-century retreat of Pine Island Glacier. Nature 541, 77-80.

Steffen, W., 2013. Commentary: Paul J. Crutzen and Eugene F. Stoermer, "The Anthropocene" (2000). In: Robin, L., Sörlin, S., Warde, P. (eds.), The Future of Nature. p.486490, Yale University Press, New Haven and London.

Steffen, W., Persson, A., Deutsch, L., Zalasiewicz, J., Williams, M., Richardson, K., Crumley, C., Crutzen, P., Folke, C., Gordon, L., Molina, M., Ramanathan, V., Rock- ström, J., Scheffer, M., Schellnhuber, H.J., Svedin, U., 2011. The Anthropocene: From Global Change to Planetary Stewardship. Ambio 40, 739-761.

Steffen, W., Richardson, K., Rockström, J., Cornell, S.E., Fetzer, I., Bennett, E.M., Biggs, R., Carpenter, S.R., de Vries, W., de Wit, C. A., Folke, C., Gerten, D., Heinke, J., Mace, G. M., Persson, L. M., Ramanathan, V., Reyers, B., Sörlin, S., 2015a. Planetary Boundaries: Guiding human development on a changing planet. Science 347 , no. 6223, 736. doi:10.1126/science. 1259855

Steffen, W., Broadgate, W., Deutsch, L., Gaffney, O., Ludwig, C., 2015b. The trajectory of the Anthropocene: the Great Acceleration. The Anthropocene Review 2, 81-98.

Steffen, W., Leinfelder, R., Zalasiewicz, J., Waters, C.N., Williams, M., Summerhayes, C., Barnosky, A.D., Cearreta, A., Crutzen, P. J., Edgeworth, M., Ellis, E. C., Fairchild, I. J., Gałuszka, A., Grinevald, J., Haywood, A., Ivar Do Sul, J., Jeandel, C., McNeill, J.R., Odada, E., Oreskes, N., Revkin, A., Richter, D. deB., Syvitski, J., Vidas, D., Wagreich, M., Wing, S.L., Wolfe, A.P., Schellnhuber, H.J., 2016. Stratigraphic and Earth System approaches in defining the Anthropocene. Earth's Future 8, 324-345.

Stöffler, N., Artemieva, A., Pierazzo, E., 2002. Modeling the Ries-Steinheim impact event and the formation of the moldavite strewn field. In: Meteoritics and Planetary Science, Journal of the Meteoritical Society, Amherst MA 37. p. 1893-1907.

Suess, E., 1862. Der Boden der Stadt Wien nach seiner Bildungsweise, Beschaffenheit und seinen Beziehungen zum Bürgerlichen Leben. Eine geologische Studie von Eduard Suess. Wilhelm Braumüller, 326 pp.

Suess, E., 1897. Der Boden der Stadt Wien und sein Relief. Geschichte der Stadt Wien, Bd. 1, 26 pp. (Herausgegeben vom Alterthumsvereine zu Wien).

Vane, C.H., Chenery, S. R., Harrison, I., Kim, A. W. MossHayes, V., Jones, D. G., 2011. Chemical signatures of the Anthropocene in the Clyde estuary, UK: sediment-hosted $\mathrm{Pb},{ }^{207 / 206} \mathrm{~Pb}$, total petroleum hydrocarbon, polyaromatic hydrocarbon and polychlorinated biphenyl pollution records. Philosophical Transactions of the Royal Society A369, 1085-1111.

Visconti, G., 2014 Anthropocene: another academic invention? Rendiconti Lincei: Science Fisiche e Naturali 25, 381-392.

Voorhies, M.R., Stover, S.G., 1978. An articulated fossil skeleton of a pregnant rhinoceros, Teleoceras major Hatcher. Proceedings of the Nebraska Academy of Sciences 88, 47-48.

Walker, M., Johnsen, S., Rasmussen, S.O., Popp, T., Steffensen, J.-P., Gibbard, P., Hoek, W., Lowe, J., Andrews, J., Björck, S., Cwynar, L.C., Hughen, K., Kershaw, P., Kromer, B., Litt, T., Lowe, D. J., Nakagawa, T., Newnham, R., Schwander, J., 2009. Formal definition and dating of the GSSP (Global Stratotype Section and Point) for the base of the Holocene using the Greenland NGRIP ice core, and selected auxiliary records. Journal of Quaternary Science 24, 3-17. 
Walker, M.J.C., Berkelhammer, M., Björck, S., Cwynar, L.C., Fisher, D. A., Long, A.J., Lowe, J.J., Newnham, R.M., Rasmussen, S.O., Weiss, H., 2012. Formal subdivision of the Holocene Series/Epoch: a Discussion Paper by a Working Group of INTIMATE (Integration of icecore, marine and terrestrial records) and the Subcommission on Quaternary Stratigraphy (International Commission on Stratigraphy). Journal of Quaternary Science 27, 649-659.

Walker, M., Gibbard, P., Lowe, J., 2015. Comment on "When did the Anthropocene begin? A mid-twentieth century boundary is stratigraphically optimal" by Jan Zalasiewicz et al. (2015). Quaternary International, doi.org/ 10.1016/j.quaint.2014.11.0450.

Walker, R. W., 2003. The Feud that sparked the Renaissance: How Brunelleschi and Ghiberti changed the Art World. Perennial-Harper Collins, New York.

Wang, H., Saito, Y., Zhang, Y., Bi, N., Sun, X., Yang, Z., 2011. Recent changes of sediment flux to the western Pacific Ocean from major rivers in East and Southeast Asia. Earth-Science Reviews 108, 80-100.

Waters, C.N., Zalasiewicz, J.A., Williams, M., Ellis, M. A., Snelling, A. M., 2014. A Stratigraphical basis for the Anthropocene? In: Waters, C.N., Zalasiewicz, J.A., Williams, M., Ellis, M.A., Snelling, A.M. (Eds.), A stratigraphical basis for the Anthropocene. Geological Society, London, Special Publications 395, p. 1-21.

Waters, C.N., Syvitski, J.P.M., Gałuszka, A., Hancock, G. J., Zalasiewicz, J., Cearreta, A., Grinevald, J., Jeandel, C., McNeill, J. R., Summerhayes, C., Barnosky, A., 2015. Can nuclear weapons fallout mark the beginning of the Anthropocene Epoch? Bulletin of the Atomic Scientists 71, 46-57.

Waters, C.N., Zalasiewicz, J., Summerhayes, C., Barnosky, A. D., Poirier, C., Gałuszka, A., Cearreta, A., Edgeworth, M., Ellis, E.C., Ellis, M., Jeandel, C., Leinfelder, R., McNeill, J.R., Richter, D. deB., Steffen, W., Syvitski, J., Vidas, D., Wagreich, M., Williams, M., An Zhisheng, Grinevald, J., Odada, E., Oreskes, N., Wolfe, A.P., 2016. The Anthropocene is functionally and stratigraphically distinct from the Holocene. Science 351, 137, http://dx. doi.org/10.1126/science.aad2622.

Webby, B.D., 1998. Steps towards a global standard for Ordovician stratigraphy. Newsletters on Stratigraphy 36, $1-33$.

Wilkinson, B.H., 2005. Humans as geologic agents: A deeptime perspective, Geology 33, 161-164.

Wilkinson, I.P., Poirier, C., Head, M.J., Sayer, C.D., Tibby, J., 2014. Microbiotic signatures of the Anthropocene in marginal marine and freshwater palaeoenvironments. In: Waters, C. N., Zalasiewicz, J. A., Williams, M., Ellis, M.A., Snelling, A. M. (eds.), A Stratigraphical Basis for the Anthropocene. Geological Society, London, Special Publications 395, p. 185-219.

Williams, M., Zalasiewicz, J., Haywood, A., Ellis, M., 2011. The Anthropocene: a new epoch of geological time? Philosophical Transactions of the Royal Society A369, no. 1938, 833-1112.
Williams, M., Zalasiewicz, J. A., Haff, P. K., Schwägerl, C., Barnosky, A.D., Ellis, E.C., 2015. The Anthropocene Biosphere. The Anthropocene Review 2, 196-219.

Williams, M., Zalasiewicz, J., Waters, C. N., Edgeworth, M., Bennett, C., Barnosky, A.D., Ellis, E.C., Ellis, M.A., Cearreta, A., Haff, P. K., Ivar do Sul, J. A., Leinfelder, R., McNeill, J.R., Odada, E., Oreskes, N., Richter, D. deB., Steffen, W., Summerhayes, C., Syvitski, J.P., Vidas, D., Wagreich, M., Wing, S. L., Wolfe, A., An Zhisheng, 2016. The Anthropocene: a conspicuous stratigraphical signal of anthropogenic changes in production and consumption across the biosphere. Earth's Future 4, doi:10.1002/2015 EF000339.

Wolfe, A.P., Csank, A.Z., Reyes, A.V., McKellar, R.C., Tappert, R., Muehlenbachs, K., 2012. Pristine Early Eocene wood buried deeply in kimberlite from Northern Canada. PLoS ONE 7, e45537.

Wolfe, A.P., Hobbs, W. O., Birks, H.H., Briner, J. P., Holmgren, S.U., Ingólfsson, Ó., Kaushal, S.S., Miller, G.H., Pagani, M., Saros, J.E., Vinebrooke, R.D., 2013. Stratigraphic expressions of the Holocene-Anthropocene transition revealed in sediments from remote lakes. Earth Science Reviews 116, 17-34.

Wolff, E.W., 2014. Ice Sheets and the Anthropocene. In: Waters, C.N., Zalasiewicz, J.A., Williams, M., Ellis, M. A., Snelling, A. M. (Eds.), A Stratigraphical Basis for the Anthropocene. Geological Society, London, Special Publications 395, p. 255-263.

Zalasiewicz, J., Williams, M., Smith, A., Barry, T.L., Coe, A.L., Bown, P.R., Brenchley, P., Cantrill, D., Gale, A., Gibbard, P., Gregory, F. J., Hounslow, M. W., Kerr, A.C., Pearson, P., Knox, R., Powell, J.H., Waters, C.N., Marshall, J., Oates, M., Rawson, P., Stone, P., 2008. Are we now living in the Anthropocene? GSA Today 18(2), 4-8.

Zalasiewicz, J., Williams, M., Fortey, R., Smith, A., Barry, T.L., Coe, A.L., Bown, P.R., Rawson, P.F., Gale, A., Gibbard, P., Gregory, F. J., Hounslow, M. W., Kerr, A.C., Pearson, P., Knox, R., Powell, J.H., Waters, C.N., Marshall, J., Oates, M., Stone, P., 2011. Stratigraphy of the Anthropocene, Philosophical Transactions of the Royal Society of London A369, 1036-1055.

Zalasiewicz, J., Crutzen, P.J., Steffen, W., 2012. The Anthropocene: Chapter 32. In: Gradstein, F. M., Ogg, J.G., Schmitz, M., Ogg G. (Eds.), The Geological Time Scale 2012. p. 1033-1040, Elsevier B.V.

Zalasiewicz, J., Waters, C.N., Williams, M. Barnosky, A., Cearreta, A., Crutzen, P., Ellis, E., Ellis, M. A., Fairchild, I. J., Grinevald, J., Haff, P. K., Hajdas, I., Leinfelder, R., McNeill, J., Odada, E. O., Poirier, C., Richter, D., Steffen, W., Summerhayes, C., Syvitski, J.P. M., Vidas, D., Wagreich, M., Wing, S.L., Wolfe, A.P., Zhishen, A., Oreskes, N., 2015a. When did the Anthropocene begin? A midtwentieth century boundary level is stratigraphically optimal. Quaternary International 383, 196-203.

Zalasiewicz, J., Waters, C.N., Barnosky, A. D., Cearreta, A., Edgeworth, M., Ellis, E.C., Gałuszka, A., Gibbard, P.L., Grinevald, J., Hajdas, I., Ivar Do Sul, J., Jeandel, C., Leinfelder, R., McNeill, J.R., Poirier, C., Revkin, A., Richter, 
D. deB., Steffen, W., Summerhayes, C., Syvitski, J.P. M., Vidas, D., Wagreich, M., Williams, M., Wolfe, A.P., 2015b. Colonization of the Americas, 'Little Ice Age' climate, and bomb-produced carbon: Their role in defining the Anthropocene. Anthropocene Review 2, 117-127.

Zalasiewicz, J., Waters, C.N., Ivar do Sul, J., Corcoran, P.L., Barnosky, A.D., Cearreta, A., Edgeworth, M., Galuszka, A., Jeandel, C., Leinfelder, R., McNeill, J.R., Steffen, W., Summerhayes, C., Wagreich, M., Williams, M., Wolfe, A.P., Yonan, Y., 2016a. The geological cycle of plastics and their use as a stratigraphic indicator of the Anthropocene. http://dx.doi.org/10.1016/j.ancene.2016. 01.002
Zalasiewicz, J., Williams, M., Waters, C.N., Barnosky, A. D., Palmesino, J., Rönnskog, A.-S., Edgeworth, M., Neal, C., Cearreta, A., Ellis, E.C., Grinevald, J., Haff, P., Ivar do Sul, J. A., Jeandel, C., Leinfelder, R., McNeill, J. R., Odada, E., Oreskes, N., Price, S.J., Revkin, A., Steffen, W., Summerhayes, C., Vidas, D., Wing, S., Wolfe, A.P. (2016b). Scale and diversity of the physical technosphere: A geological perspective. The Anthropocene Review, doi: $10.1177 / 2053019616677743$

Manuscript received: October 8, 2016

Revised version accepted: December 12, 2016 